Prepared in cooperation with the U.S. Department of the Army Environmental and Natural Resources Management Office of the U. S. Army Signal Center and Fort Gordon

\title{
Assessment of Soil-Gas Contamination at Building 310 Underground Storage Tank Area, Fort Gordon, Georgia, 2010-2011
}

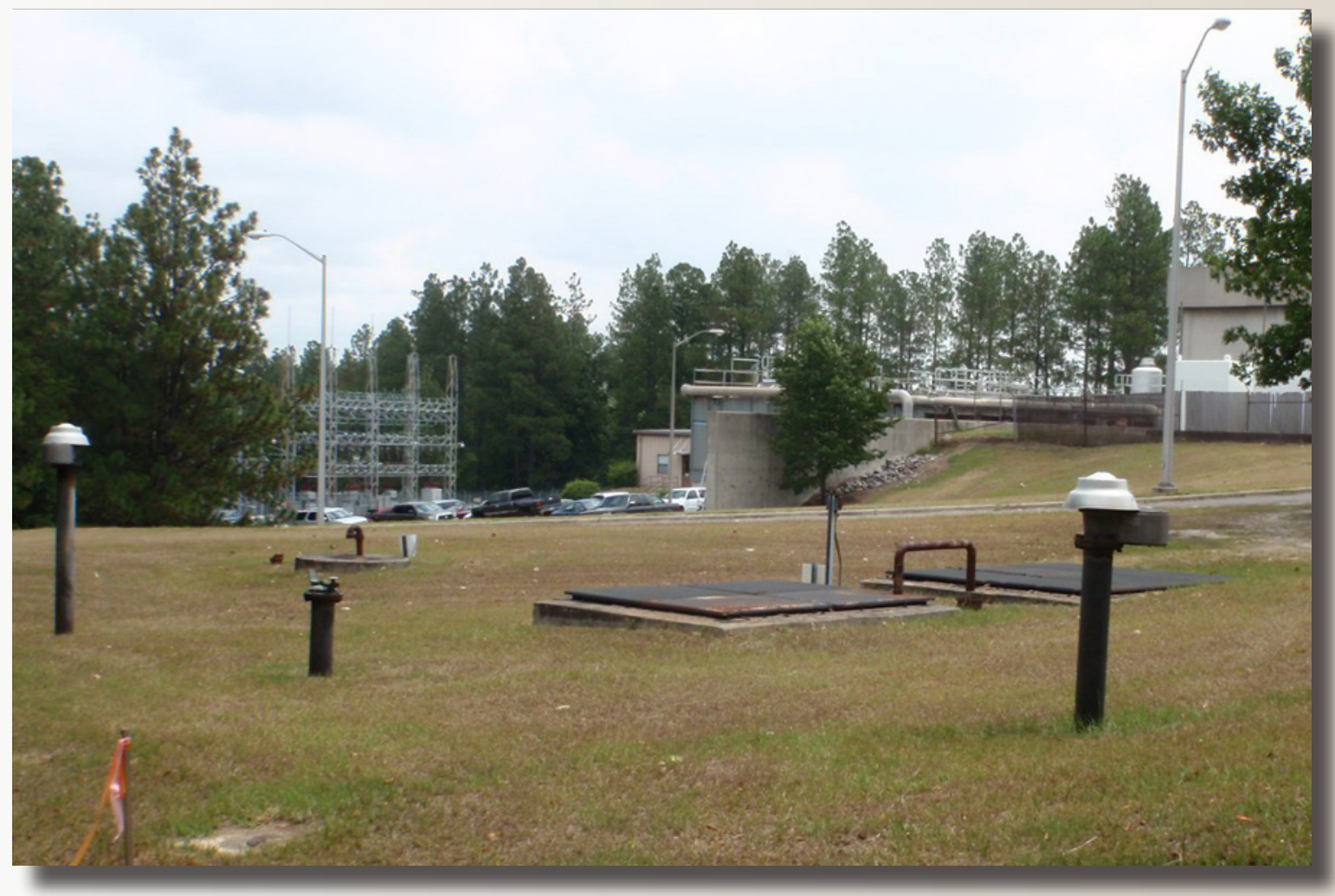

Open-File Report 2012-1136 
Cover. Site of underground storage tanks at building 310 area, Fort Gordon, Georgia. Photograph by W. Fred Falls, USGS. 


\section{Assessment of Soil-Gas Contamination at Building 310 Underground Storage Tank Area, Fort Gordon, Georgia, 2010-2011}

By Wladmir B. Guimaraes, W. Fred Falls, Andral W. Caldwell, W. Hagan Ratliff, John B. Wellborn, and James E. Landmeyer

Prepared in cooperation with the U.S. Department of the Army Environmental and Natural Resources Management Office of the U.S. Army Signal Center and Fort Gordon

Open-File Report 2012-1136 


\section{U.S. Department of the Interior \\ KEN SALAZAR, Secretary \\ U.S. Geological Survey \\ Marcia K. McNutt, Director}

\section{U.S. Geological Survey, Reston, Virginia: 2012}

For more information on the USGS — the Federal source for science about the Earth, its natural and living resources, natural hazards, and the environment, visit http://www.usgs.gov or call 1-888-ASK-USGS.

For an overview of USGS information products, including maps, imagery, and publications, visit http://www.usgs.gov/pubprod

To order this and other USGS information products, visit http://store.usgs.gov

Any use of trade, product, or firm names is for descriptive purposes only and does not imply endorsement by the U.S. Government.

Although this report is in the public domain, permission must be secured from the individual copyright owners to reproduce any copyrighted materials contained within this report.

Suggested citation:

Guimaraes, W.B., Falls, W.F., Caldwell, A.W., Ratliff, W.H., Wellborn, J.B., and Landmeyer, J.E., 2012, Assessment of soil-gas contamination at building 310 underground storage tank area, Fort Gordon, Georgia, 2010-2011: U.S. Geological Survey Open-File Report 2012-1136, 30 p. 


\section{Contents}

Abstract
Introduction.
Purpose and Scope
Description of the Study Area
Methods
Soil-Gas Survey
Selected References

\section{Figures}

Maps showing:

1. Location of the building 310 underground storage tank area,

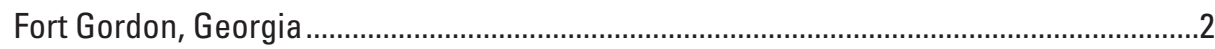

2. Soil-gas sampler $A$, prior to being installed in a shallow borehole; and $B$, following retrieval from a borehole and prior to shipping to the laboratory for analysis

3. Locations of soil-gas sampling sites, building 310 underground storage tank area, Fort Gordon, Georgia, 2010-2011

4. Total petroleum hydrocarbons mass in soil-gas samplers, building 310 underground storage tank area, Fort Gordon, Georgia, July 2011.

5. Combined masses of benzene, toluene, ethylbenzene, and total xylenes in soil-gas samplers, building 310 underground storage tank area, Fort Gordon, Georgia, July 2011.

6. Locations of benzene, toluene, and $m-, p$-zylene mass in soil-gas samplers, building 310 underground storage tank area, Fort Gordon, Georgia, July 2011.

7. Combined masses of undecane, tridecane, and pentadecane in soil-gas samplers, building 310 underground storage tank area, Fort Gordon, Georgia, July 2011

8. Undecane mass in soil-gas samplers, building 310 underground storage tank area, Fort Gordon, Georgia, July 2011

9. Tridecane mass in soil-gas samplers, building 310 underground storage tank area, Fort Gordon, Georgia, July 2011

10. Pentadecane mass in soil-gas samplers, building 310 underground storage tank area, Fort Gordon, Georgia, July 2011

11. Chloroform mass in soil-gas samplers, building 310 underground storage tank area, Fort Gordon, Georgia, July 2011.

\section{Table}

1. Mass of organic compounds detected in soil-gas samplers, 310 underground storage tank, Fort Gordon, Georgia, 2010-2011 


\section{Conversion Factors}

Inch/Pound to SI

\begin{tabular}{|c|c|c|}
\hline Multiply & By & To obtain \\
\hline \multicolumn{3}{|c|}{ Length } \\
\hline inch (in.) & 2.54 & centimeter $(\mathrm{cm})$ \\
\hline inch (in.) & 25.4 & millimeter (mm) \\
\hline foot (ft) & 0.3048 & $\operatorname{meter}(\mathrm{m})$ \\
\hline mile (mi) & 1.609 & kilometer (km) \\
\hline gallon (gal) & 3.785 & liter $(\mathrm{L})$ \\
\hline
\end{tabular}

Horizontal coordinate information is referenced to the North American Datum of 1983 (NAD 83).

Selected acronyms and abbreviations:

BTEX Benzene, toluene, ethylbenzene, and xylene (total)

$\mathrm{mL} \quad$ milliliter

$\mu \mathrm{g} \quad$ microgram

$\mu \mathrm{g} / \mathrm{L} \quad$ microgram per liter

MDL Method detection level

MTBE Methyl tert-butyl ether

PAH Polycyclic aromatic hydrocarbon

PCE Perchloroethylene (also known as tetrachloroethylene)

SVOC Semivolatile organic compound

TCE Trichloroethylene

TPH Total petroleum hydrocarbon

USEPA U.S. Environmental Protection Agency

USGS U.S. Geological Survey

VOC Volatile organic compound 


\title{
Assessment of Soil-Gas Contamination at Building 310 Underground Storage Tank Area, Fort Gordon, Georgia, 2010-2011
}

\author{
By Wladmir B. Guimaraes, ${ }^{1}$ W. Fred Falls, ${ }^{1}$ Andral W. Caldwell, ${ }^{1}$ W. Hagan Ratliff, ${ }^{2}$ John B. Wellborn, ${ }^{3}$ and \\ James E. Landmeyer ${ }^{1}$
}

\section{Abstract}

Soil gas was assessed for contaminants in the building 310 underground storage tank area adjacent to the Dwight D. Eisenhower Army Medical Center at Ft. Gordon, Georgia, from October 2010 to September 2011. The assessment, which also included the detection of organic compounds in soil gas, provides environmental contamination data to Fort Gordon personnel pursuant to requirements of the Resource Conservation and Recovery Act Part B Hazardous Waste Permit process. The study was conducted by the U.S. Geological Survey, in cooperation with the U.S. Department of the Army Environmental and Natural Resources Management Office of the U.S. Army Signal Center and Fort Gordon.

Soil-gas samplers were deployed below land surface at 37 locations in the building 310 underground storage tank area. Soil-gas samplers were deployed in a grid pattern near the storage tank area as well as downslope of the tank area in the direction of groundwater flow toward an unnamed tributary to Butler Creek. Total petroleum hydrocarbons were detected in 35 of the 37 soil-gas samplers at levels above the method detection level, and the combined mass of benzene, toluene, ethylbenzene, and total xylenes were detected above their detection levels in 8 of the 37 samplers. In addition, the combined masses of undecane, tridecane, and pentadecane were detected at or above their method detection levels in 9 of the 37 samplers. Other volatile organic compounds detected above their respective method detection levels were chloroform, 1,2,4-trimethylbenzene, and perchloroethylene. In addition, naphthalene, 2-methyl naphthalene, and 1,2,4-trimethylbenzene were detected below the method detection levels, but above the nondetection level.

${ }^{1}$ U.S. Geological Survey, Columbia, South Carolina.

${ }^{2}$ Environmental Branch, Fort Gordon, Georgia.

${ }^{3}$ Environmental and Natural Resources, Fort Gordon, Georgia.

\section{Introduction}

Fort Gordon is a U.S. Department of the Army facility located in east-central Georgia, approximately 10 miles (mi) southwest of Augusta, Georgia (fig. 1). A cantonment (military housing) area is located at the northwestern boundary of Fort Gordon. Underground storage tanks (USTs) are located in open area, adjacent to East Hospital Road, near the Dwight D. Eisenhower Army Medical Center (fig. 1). A 200,000 gallon UST is located directly behind a small powerplant identified as building 310. The tank is currently (2011) used for fuel storage. The ground is directly above the UST, but slopes away from the tanks to a tributary to Butler Creek in the northeast part of the cantonment area at Fort Gordon. Little information is available about the USTs behind building 310 (310 UST) except that petroleum products were stored in the tanks (Hagan Ratliff, Applied Services and Informational Systems, Inc., Installation Restoration Program Manager, oral commun., November 6, 2009). An initial investigation to study the possible contamination of the soil is warranted for the 310 UST because no historical information is available about the activities and use of the site. Additionally, the site is located in the outcrop area for the Cretaceous-age aquifer system which is used for drinking water farther downgradient (Williams, 2007). Groundwater from the 310 UST area may discharge to streams in the area, enabling potential contaminants to be transported off the Fort Gordon property.

\section{Purpose and Scope}

The 310 UST area represents a potential source of contamination to the water resources of the area. The U.S. Geological Survey, in cooperation with the U.S. Department of the Army Environmental and Natural Resources Management Office of the U.S. Army Signal Center and Fort Gordon, Georgia, conducted an assessment of soil gas for contaminants at the 310 UST area in July 2011. This assessment was conducted to provide environmental contamination data to personnel at Fort Gordon. A preliminary survey of the area was 

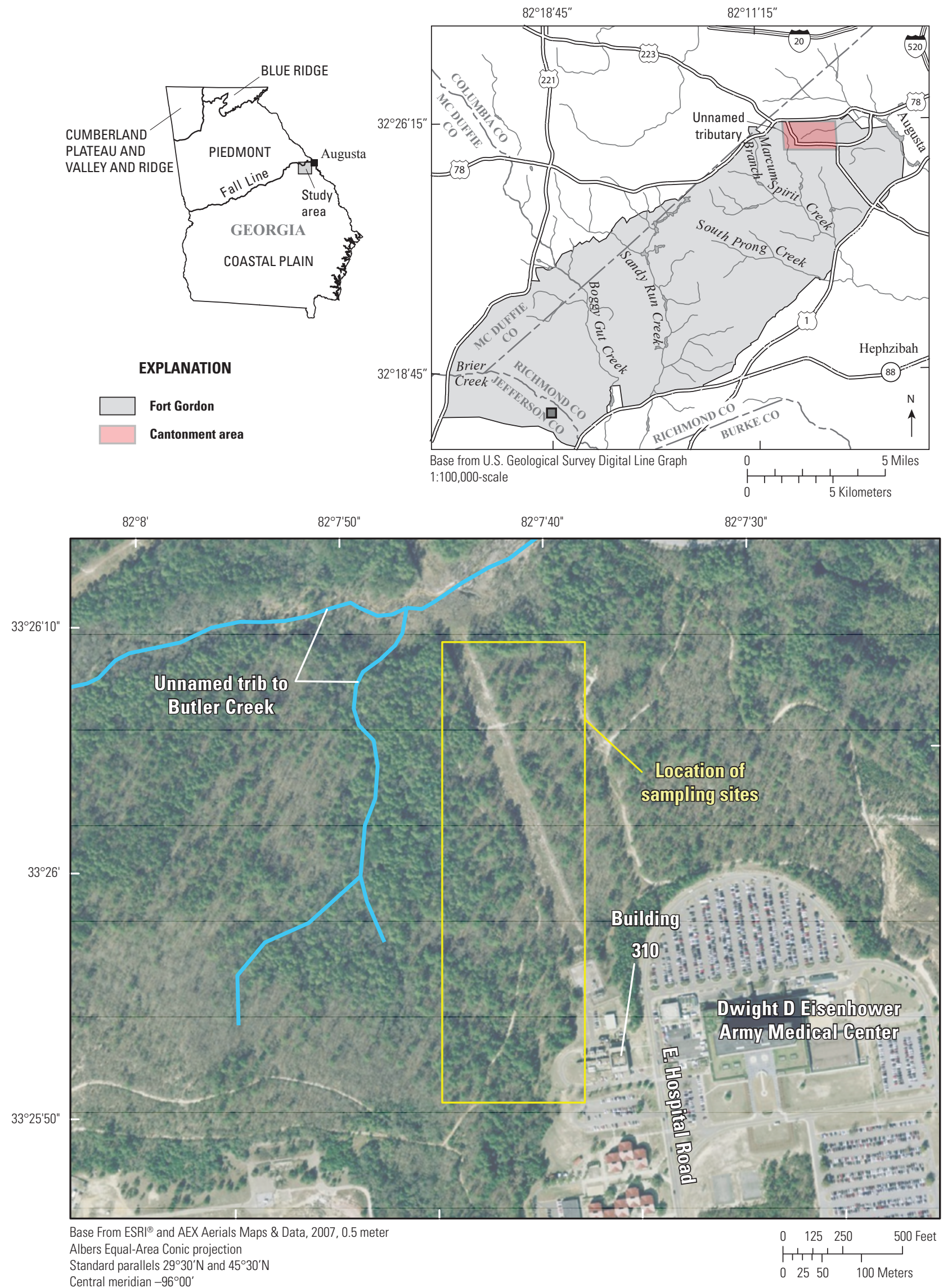

Figure 1. Location of the building 310 underground storage tank area, Fort Gordon, Georgia. 
conducted in 2010 to identify possible areas of contamination. This report provides the results of analyses of these samplers.

\section{Description of the Study Area}

Fort Gordon is an Army facility located in east-central Georgia, approximately $10 \mathrm{mi}$ southwest of Augusta, Georgia (fig. 1). Fort Gordon lies in the northern part of the Coastal Plain Physiographic Province and south of the Fall Line. Surficial soil and sediments are characterized by unconsolidated sands, indurated sands and semiconsolidated sandstones, and layers of clay that include kaolinite (Gregory and others, 2001).

\section{Methods}

All soil-gas samplers were installed, retrieved, and analyzed in July 2011 using standard laboratory practices (U.S. Geological Survey, variously dated). The methods were selected to provide data to determine the presence or absence of contamination in the soil gas. The soil-gas method that was used provides results that are qualitative and not quantitative.

\section{Soil-Gas Survey}

The passive survey used the GORETM Module (soil-gas samplers), a commercially available passive diffusion sampler based on GORE-TEX ${ }^{\circledR}$ membrane technology (U.S. Environmental Protection Agency, 1998; W.L. Gore and Associates, Inc., 2004; American Society for Testing and Materials, 2006). The soil-gas samplers consist of an adsorbent material placed inside a shoestring-shaped GORE-TEX ${ }^{\circledR}$ tube (fig. $2 A$ ). The adsorbent material can adsorb a wide variety of volatile organic compounds (VOC), including solvents such as perchloroethylene (PCE; also known as tetrachloroethylene); trichloroethylene (TCE); benzene, toluene, ethylbenzene, and xylenes (collectively referred to as BTEX); methyl tert-butyl ether (MTBE); semivolatile organic compounds (SVOC); total petroleum hydrocarbons (TPH); and polycyclic aromatic hydrocarbons (PAH), such as naphthalene. The soil-gas samplers were tied to a string, attached to a cork plug to prevent the entrance of surface water and ambient surface sources of contamination, inserted into a shallow borehole, and later removed after 5 to 10 days. After the samplers were removed, they were placed in their original 20-milliliter $(\mathrm{mL})$ gas-tight vial (fig. $2 B$ ) and sent to a commercial laboratory (W.L. Gore and Associates, Inc.) for analysis by gas chromatography/mass spectroscopy, using a modification of U.S. Environmental Protection Agency (USEPA) method 8260/8270 to include thermal desorption of the sample. The laboratory is in compliance with Good Laboratory Practices and ISO Guide 25 (International Organization for Standardization, 1990).

A total of 37 soil-gas samplers were deployed in a grid pattern to cover the generalized extent of the 310 UST and are
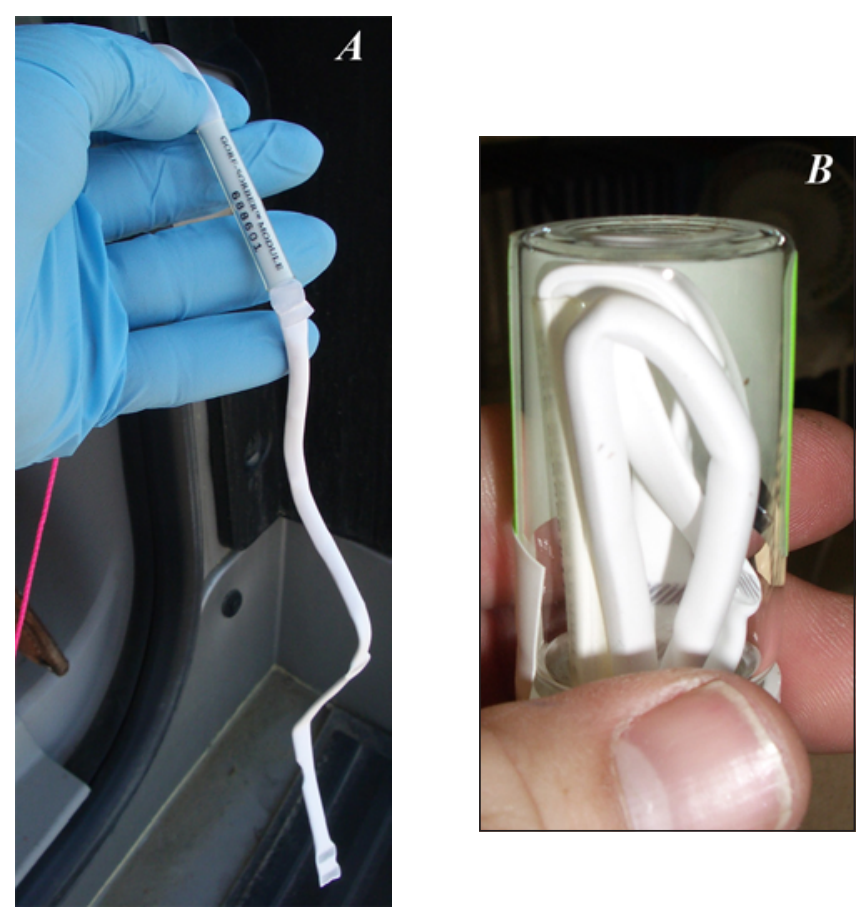

Figure 2. Soil-gas sampler $A$, prior to being installed in a shallow borehole; and $B$, following retrieval from a borehole and prior to shipping to the laboratory for analysis.

also installed downgradient toward an unnamed tributary to Butler Creek (fig. 3). Each soil-gas sampler was placed in a borehole, created by a stainless steel ship auger attached to a cordless drill, measuring 0.5 inches (in.) in diameter and 15-in. long. The sampling depth is similar to that recommended by the USEPA for soil-gas investigations (U.S. Environmental Protection Agency, 1998). The auger was cleaned with a paper towel between boreholes. The 37 soil-gas sampler modules were installed on July 20, 2011, and were removed on July 27, 2011. Five additional soil-gas samplers were used as trip blanks and two samplers used as method blanks and these were not deployed. The soil-gas contaminant results are expressed as mass of contaminant in micrograms.

\section{Results}

Passive survey results can indicate the presence of particular contaminants. The results do not, however, reveal if the detection was derived from a free product, a residual-phase adsorbed material, vapors in the unsaturated zone, or from the dissolved phase in shallow and deep groundwater. In general, higher mass of a compound in a sampler tends to be related to the presence of residual contamination or free product that is close to the land surface where the sampler is located. If such source material were located at greater depths, however, the contaminant mass generally would be lower. A lower mass of a compound near known sources of contaminants could be due to various attenuation processes that affect the mass prior to detection. In both cases, however, the soil-gas samplers help 


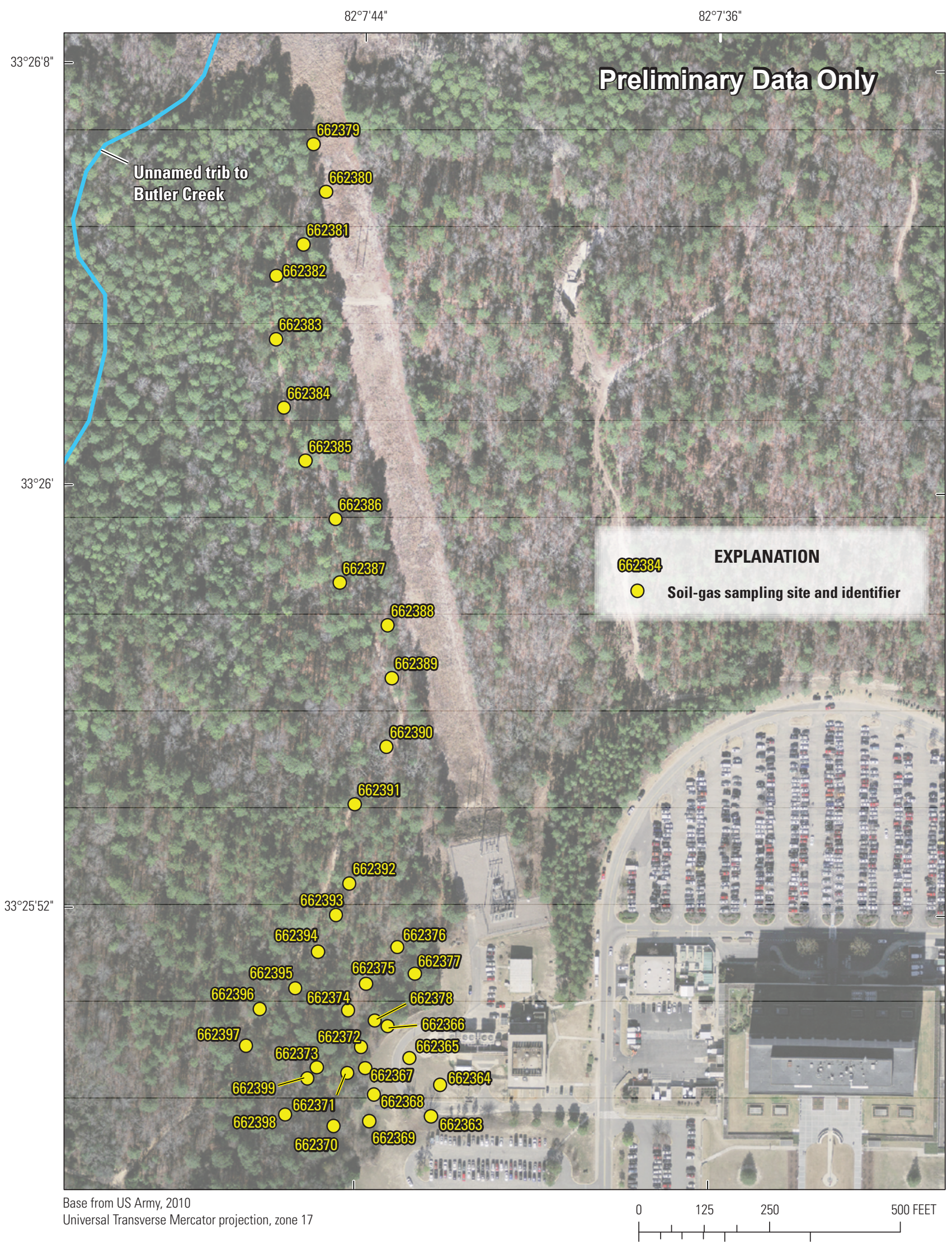

Figure 3. Locations of soil-gas sampling sites, building 310 underground storage tank area, Fort Gordon, Georgia, 2010-2011. 
to rapidly indicate the presence or absence of contaminants. The passive approach was approved for use at the 310 UST area by the Hazardous Waste Management Branch, Georgia Environmental Protection Department (William Powell, P.E., Environmental Engineer, Department of Defense Remediation Unit, oral commun., December 10, 2008).

\section{Soil-Gas Survey}

A total of 35 of the 37 soil-gas samplers deployed at the 310 UST area detected TPH mass greater than the method detection level (MDL) of 0.02 microgram $(\mu \mathrm{g})$ (fig. 4, table 1; table 1 shown on p. 16); the other 2 samplers detected TPH below its MDL but above the nondetection level. The highest soil-gas TPH mass was $34.89 \mu \mathrm{g}$ and was located in sampler number 662373. The TPH mass ranged from 0.02 to $34.89 \mu \mathrm{g}$. Two of the highest detected masses of TPH were detected downslope near an unnamed tributary to Butler Creek (sampler numbers 662381 and 662385). One trip blank (sampler number 662359) detected TPH mass at 0.08 $\mu \mathrm{g}$, which is above the $0.02 \mu \mathrm{g}$ MDL. Two other trip blanks (sampler numbers 662358 and 662360) detected the presence of TPH at levels below the MDL, but above its nondetection level. Censoring of soil-gas results can be difficult because the results are not quantitative, but they do indicate the presence of the constituent. For TPH, the mass in the soil-gas samples detected below the level of the $0.08-\mu \mathrm{g}$ mass detected in one trip blank is considered questionable. TPH mass at two times greater than the mass detected in the trip blank, or $0.16 \mu \mathrm{g}$, is considered likely to be an environmental sample, and TPH mass greater than $8 \mu \mathrm{g}$, or 10 times than the value detected in the trip blank, is very likely to be representative of environmental conditions. The only other constituents detected in the trip blanks were undecane, tridecane, and pentadecane which were detected below their respected MDLs, but above the nondetection levels. The detected mass for undecane, tridecane, and pentadecane generally were many times greater than the mass detected in the trip blanks; therefore, the results for the mass of undecane, tridecane, and pentadecane are considered to represent environmental conditions. BTEX was detected in 8 of the 37 samplers in the 310 UST area above each respective MDLs (fig. 5, table 1). Benzene and toluene were the main components of the BTEX mass detected above their MDL in 7 samplers. Benzene was detected in 3 samplers (sampler numbers 662367, 662384, and 662395; fig. 6, table 1 ) and toluene was detected in 4 samplers (sampler numbers 662373, 662377, 662381, and 662385; fig. 6, table 1). Benzene and toluene were detected downslope near the unnamed tributary to Butler Creek (sampler numbers 662381, 662384, and 662385). The compound $m$-, $p$-xylene was detected at one location (sampler 662363; fig. 6, table 1). 


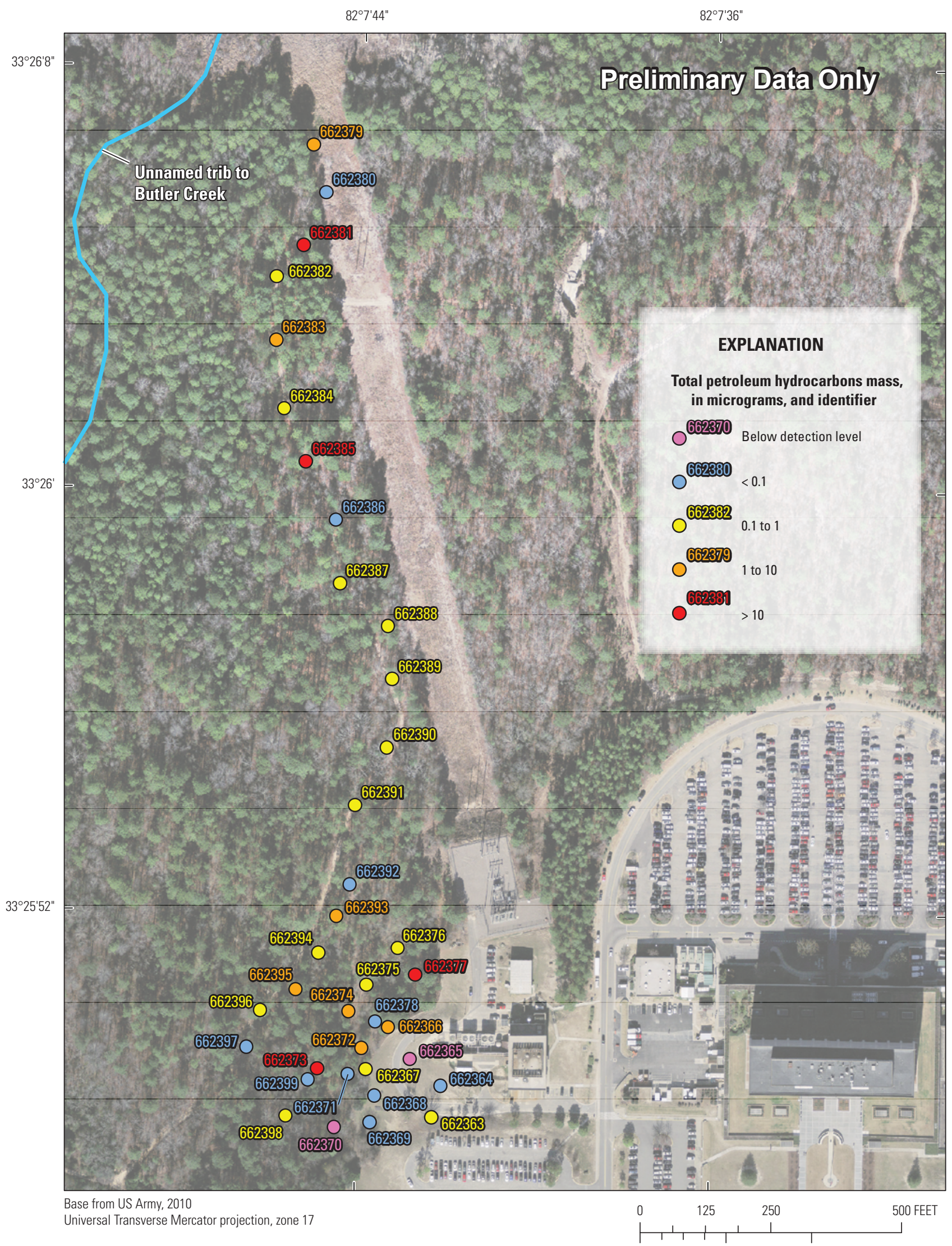

Figure 4. Total petroleum hydrocarbons mass in soil-gas samplers, building 310 underground storage tank area, Fort Gordon, Georgia, July 2011. 
$82^{\circ} 7^{\prime} 44^{\prime \prime}$

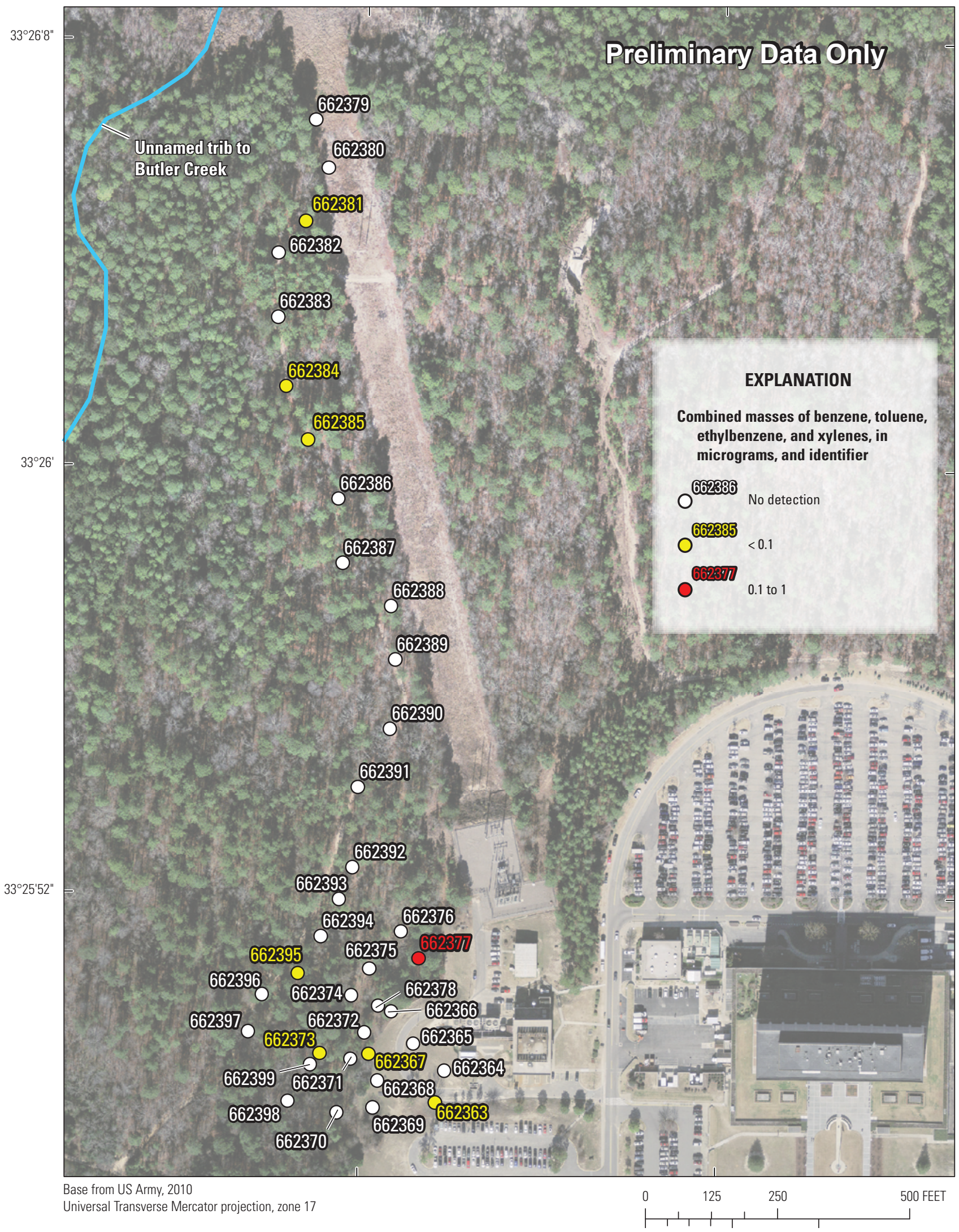

Figure 5. Combined masses of benzene, toluene, ethylbenzene, and total xylenes in soil-gas samplers, building 310 underground storage tank area, Fort Gordon, Georgia, July 2011. 


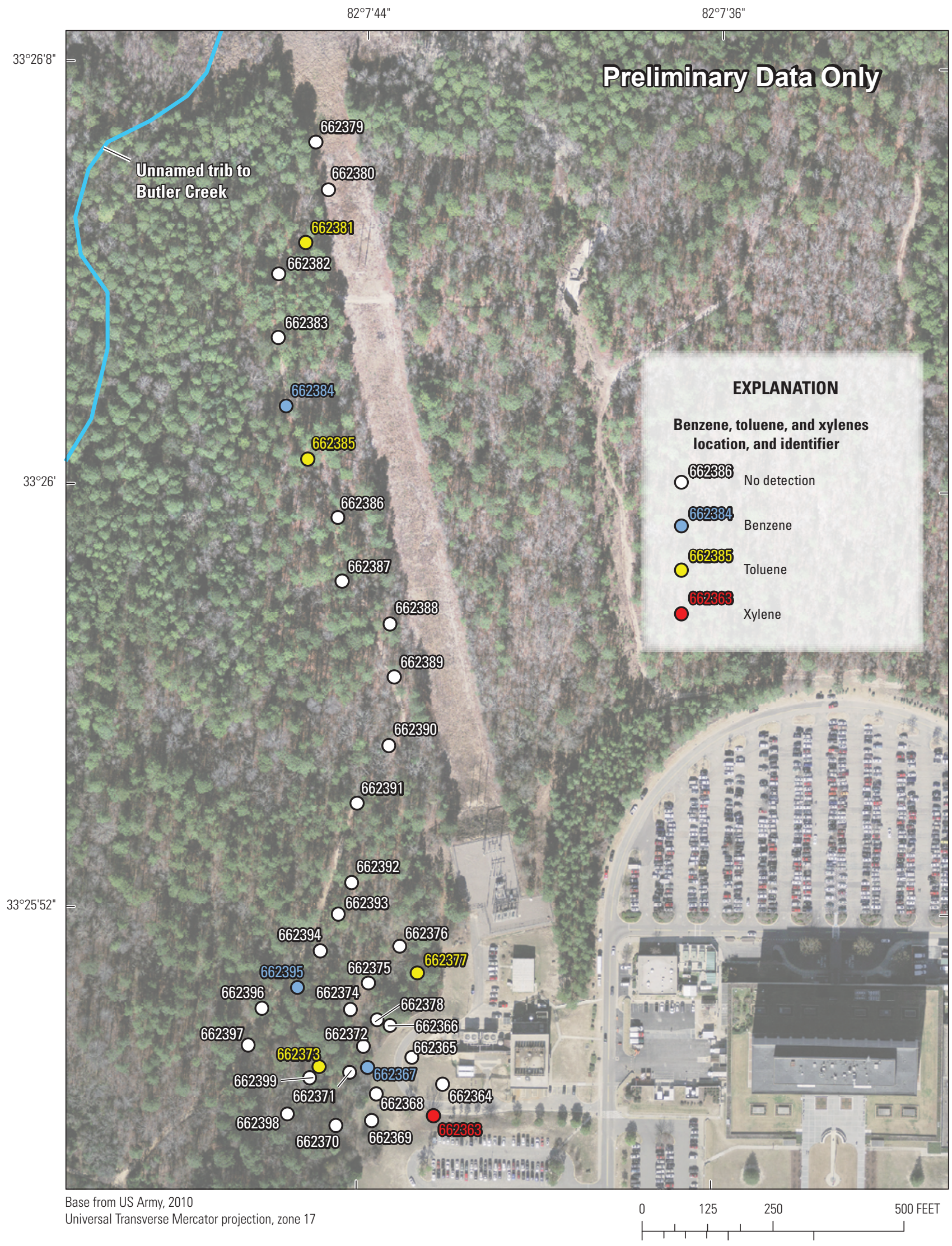

Figure 6. Locations of benzene, toluene, and $m$-, $p$-zylene mass in soil-gas samplers, building 310 underground storage tank area, Fort Gordon, Georgia, July 2011. 
Two PAHs, naphthalene (sampler numbers 662366) and 2-methyl-napthalene (sampler number 662373), were detected below their MDL, but above the nondetection level (table 1). The combined masses of the alkanes, undecane, tridecane, and pentadecane $\left(\mathrm{C}_{11}, \mathrm{C}_{13}\right.$, and $\left.\mathrm{C}_{15}\right)$, were detected at or above their MDLs in 9 of the 37 samplers (fig. 7, table 1) and below their MDLs, but above the nondetection levels in 7 of the 37 samplers (table 1). Undecane was detected above its MDL in 5 samplers (sampler numbers 662366, 662372, 662379, 662381, and 662387; fig. 8, table 1) with 3 samplers located downslope near the unnamed tributary to Butler Creek (sampler numbers 662379, 662381, and 662387). Tridecane was detected above its MDL in 4 samplers (sampler numbers
662366, 662372, 662373, and 662381; fig. 9, table 1) with one sampler located downslope near the unnamed tributary to Butler Creek Sampler number 662381). In addition, pentadecane was detected above its MDL in 4 samplers (sampler numbers 662376, 662377, 662381, 66293; fig.10, table 1) with 1 sampler located downslope near the unnamed tributary to Butler Creek (sampler number 662381). Other VOCs detected in the soil-gas survey above their MDL included chloroform in sampler numbers 662381, 662382, 662386, 662387, 662390, 662391, 662393 and 662394 (fig. 11, table 1), 1,2,4-trimethylbenzene in sampler number 662363 , and PCE in sampler number 662382 (table 1). Most of the chloroform detected was downslope near the unnamed tributary to Butler Creek. 
$82^{\circ} 74^{\prime} 44^{\prime \prime}$

$82^{\circ} 7^{\prime} 36^{\prime \prime}$

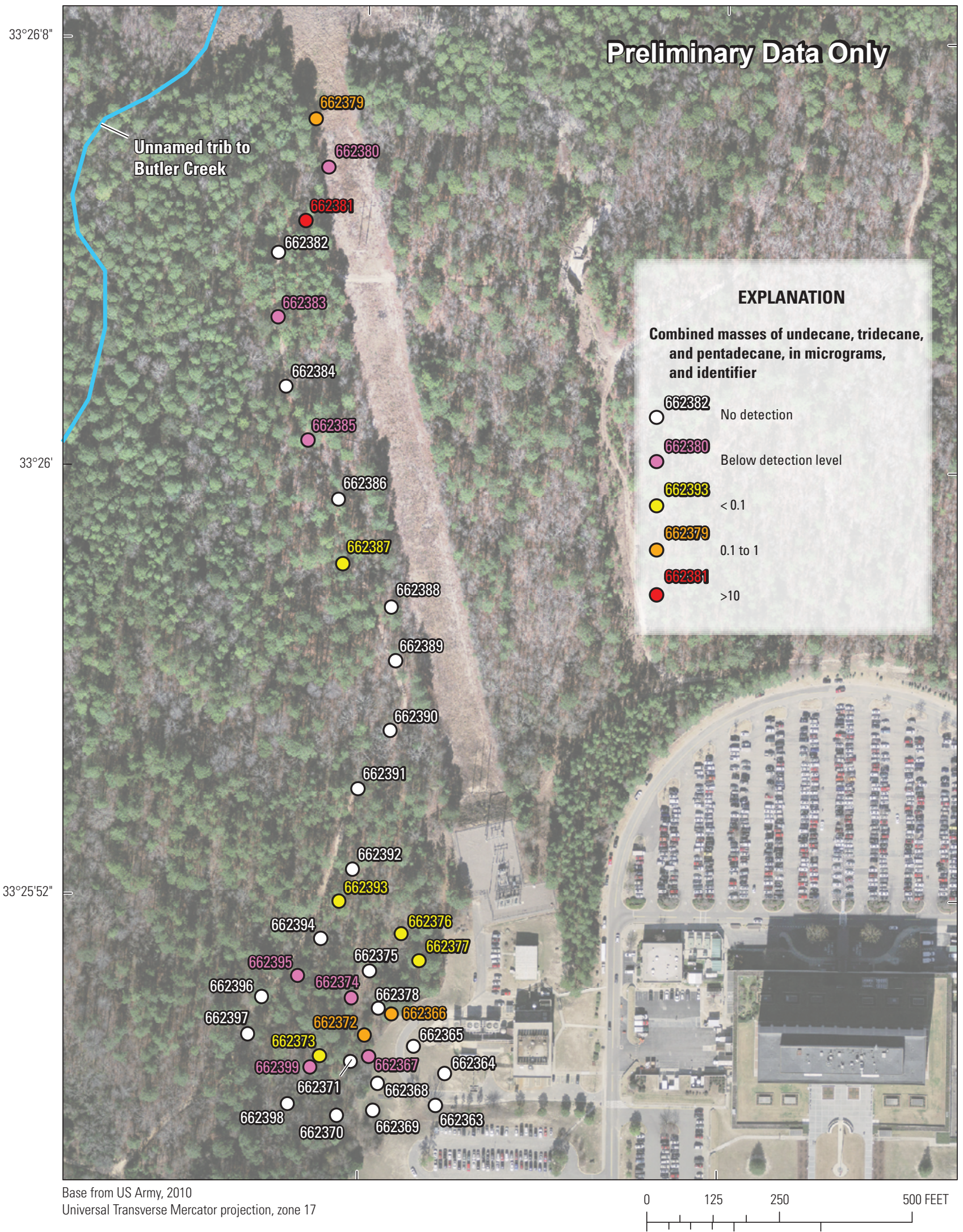

Figure 7. Combined masses of undecane, tridecane, and pentadecane in soil-gas samplers, building 310 underground storage tank area, Fort Gordon, Georgia, July 2011. 


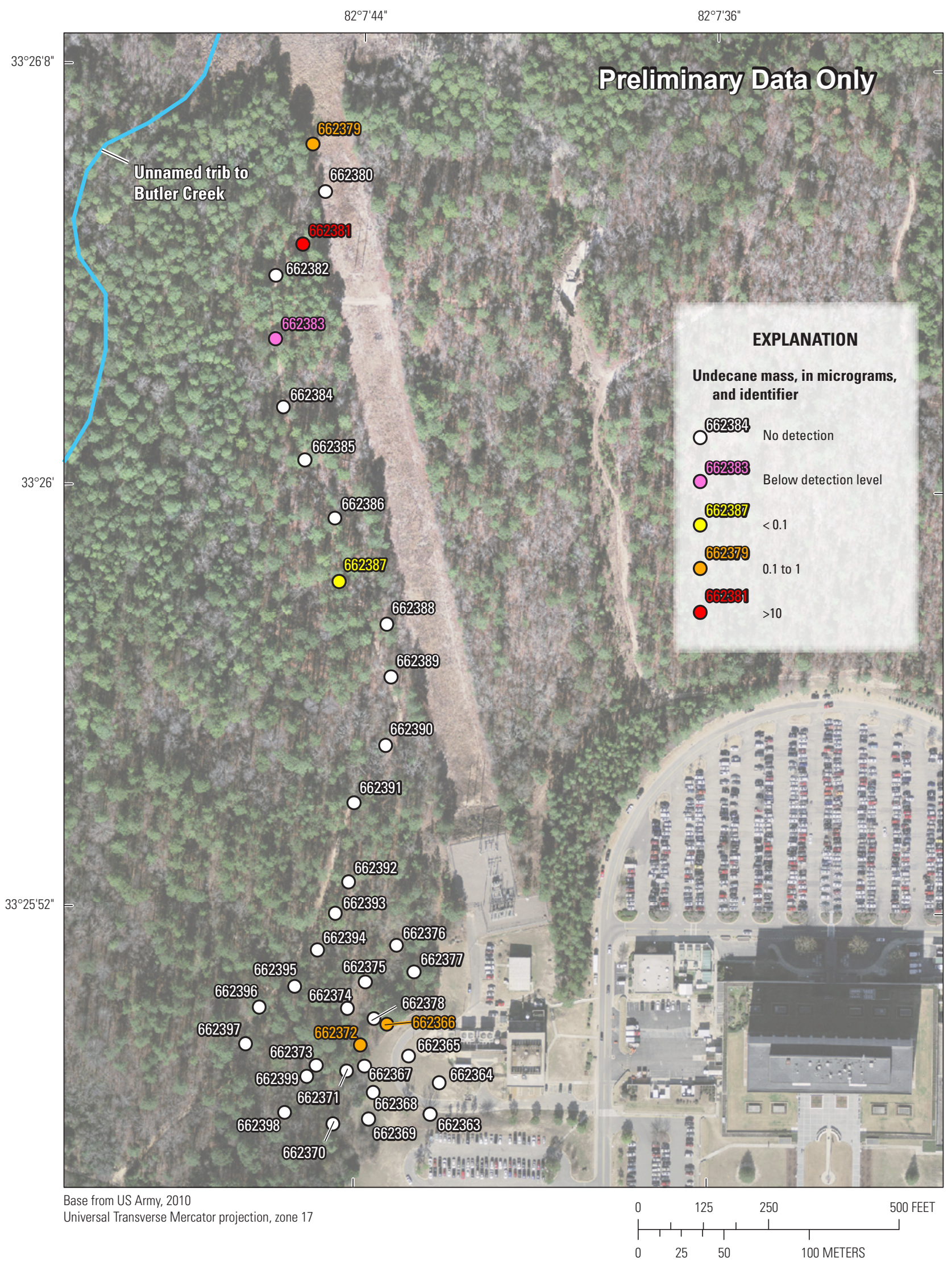

Figure 8. Undecane mass in soil-gas samplers, building 310 underground storage tank area, Fort Gordon, Georgia, July 2011. 


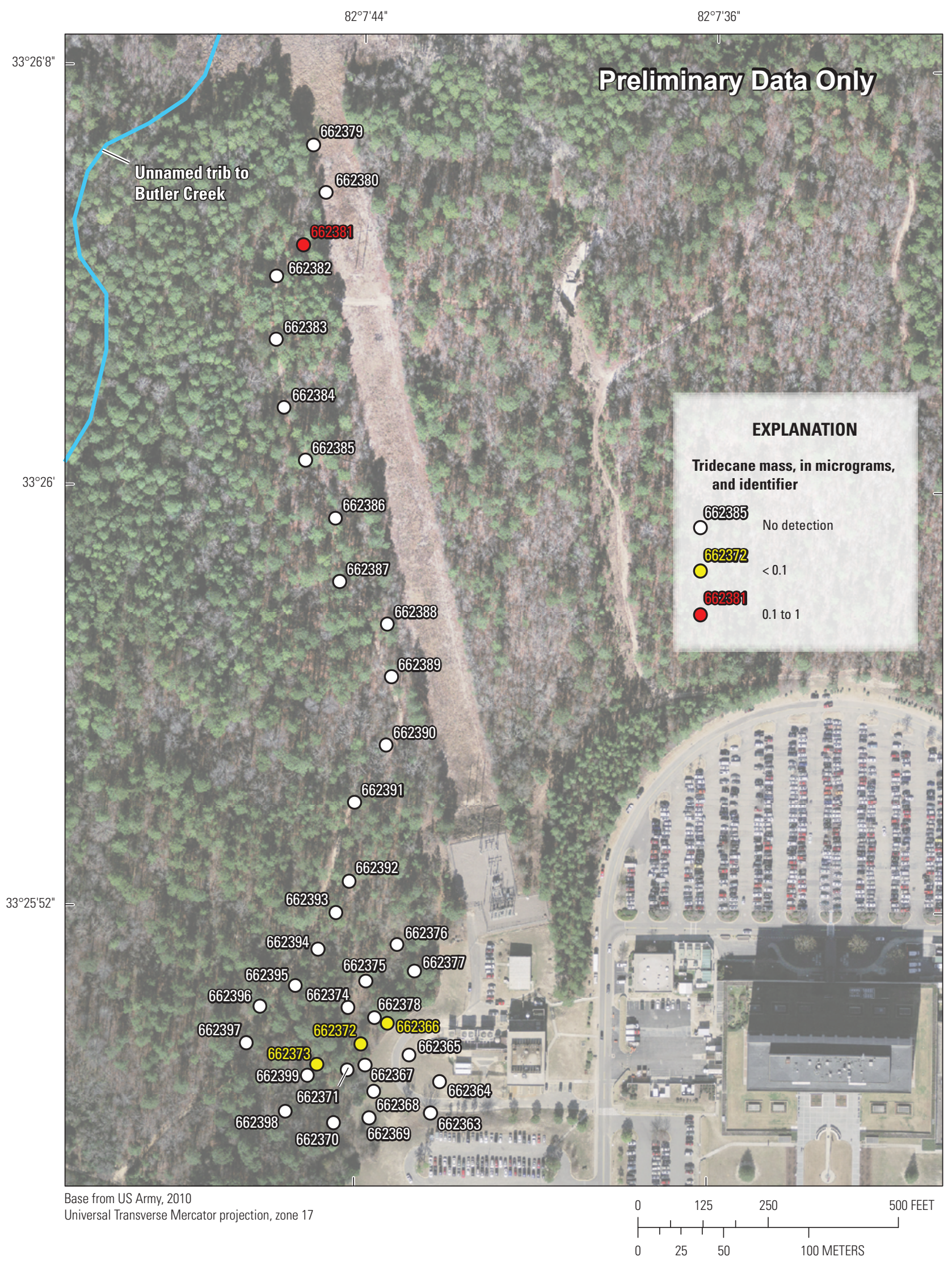

Figure 9. Tridecane mass in soil-gas samplers, building 310 underground storage tank area, Fort Gordon, Georgia, July 2011. 


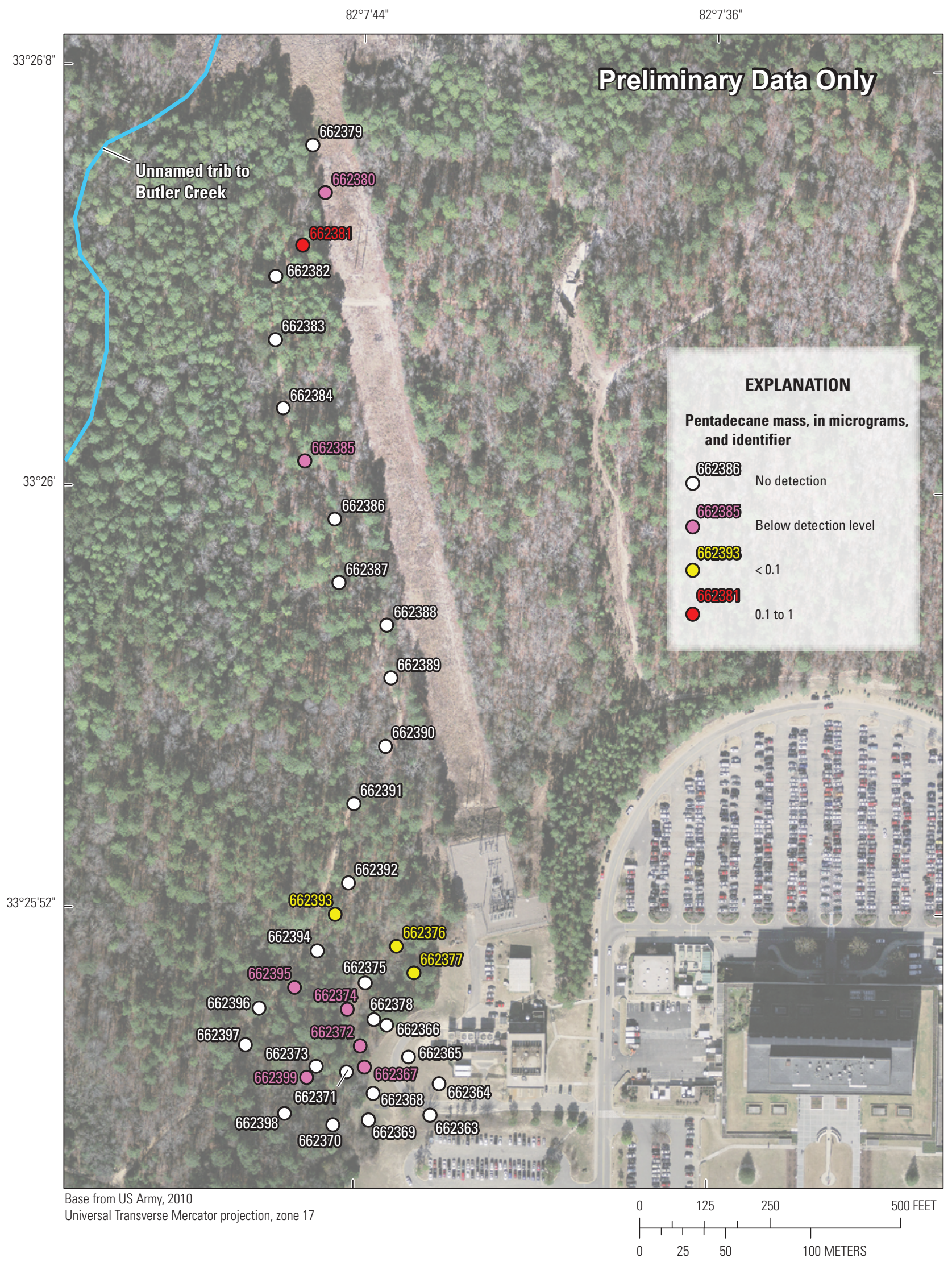

Figure 10. Pentadecane mass in soil-gas samplers, building 310 underground storage tank area, Fort Gordon, Georgia, July 2011. 


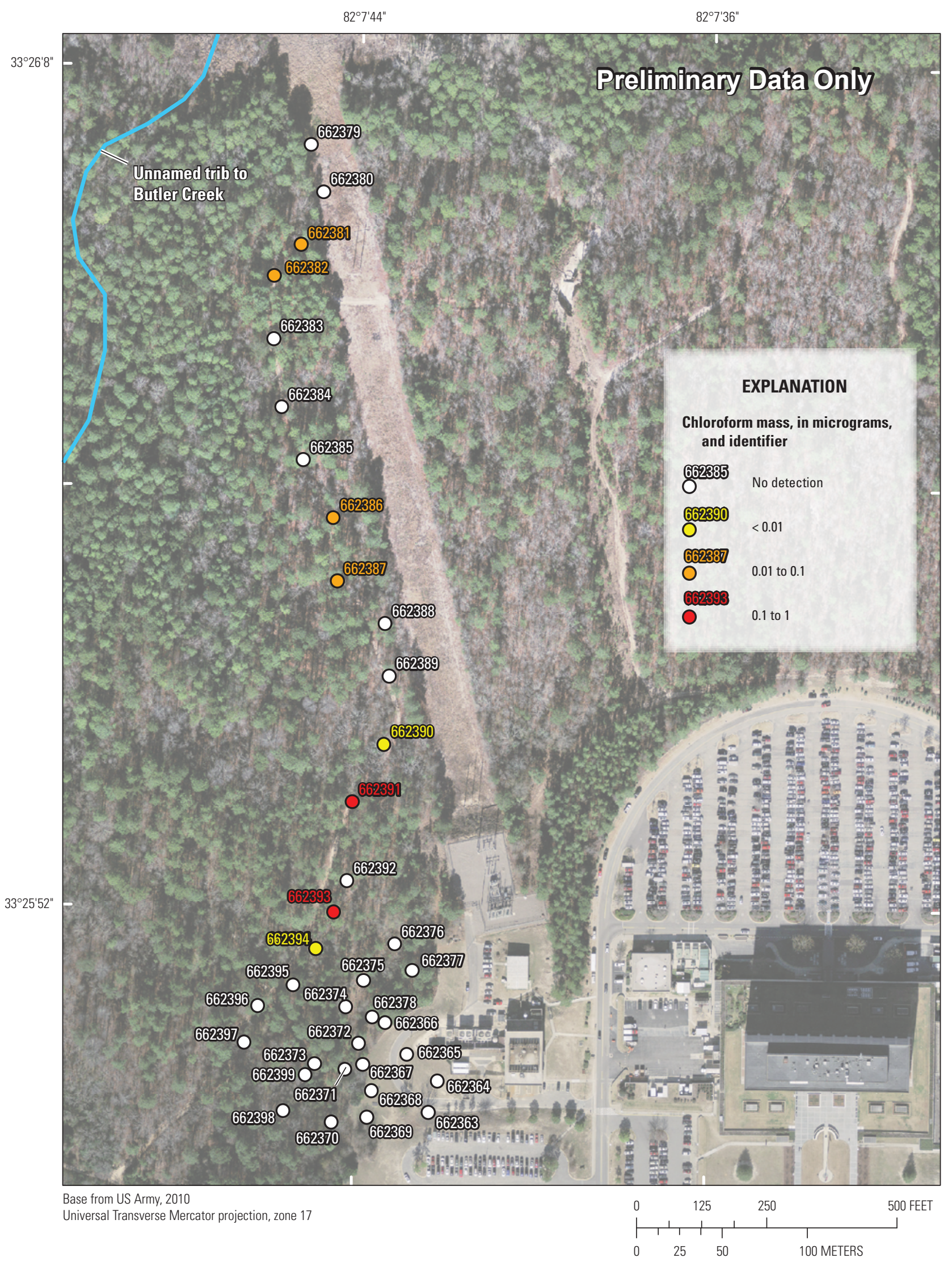

Figure 11. Chloroform mass in soil-gas samplers, building 310 underground storage tank area, Fort Gordon, Georgia, July 2011. 


\section{Summary}

The U.S. Geological Survey, in cooperation with the Environmental and Natural Resources Management Office of the U.S. Army Signal Center and Fort Gordon, Georgia, assessed soil gas for contaminants near the building 310 underground storage area near the Dwight D. Eisenhower Army Medical Center at Fort Gordon, Georgia, from October 2010 to September 2011. The assessment included the detection of organic compounds in soil gas. The assessment was conducted to provide environmental contamination data to Fort Gordon personnel pursuant to requirements of the Resource Conservation and Resources Act Part B Hazardous Permit process.

A total of 37 passive soil-gas samplers were deployed above and near the underground storage tanks near building 310 , and downslope toward a tributary to Butler Creek. Of the 37 samplers, 35 samplers detected the presence of total petroleum hydrocarbons greater than its method detection level (MDL). Combined masses of benzene, toluene, ethylbenzene, and total xylenes (BTEX) were detected above their MDLs in 8 of the 37 samplers. The combined masses of undecane, tridecane, and pentadecane were detected above their MDLs in 9 of the 37 samplers. Other volatile organic compounds detected above their respective MDLs in the soil-gas survey included chloroform, 1,2,4-trimethylbenzene, and perchloroethylene.

\section{Selected References}

American Society for Testing and Materials, 2006, Standard guide for soil gas monitoring in the vadose zone: ASTM D5314-92, $36 \mathrm{p}$.

Gregory, M.B., Stamey, T.C., and Wellborn, J.B., 2001, Ecological characterization of streams, and fish-tissue analysis for mercury and lead at selected locations, Fort Gordon, Georgia, June 1999 to May 2000: U.S. Geological Survey Open-File Report 01-203, 14 p.

International Organization for Standardization, 1990, ISO Guide 25: General requirements for the competence of calibration and testing laboratories (3d ed.): New York, American National Standards Institute.

U.S. Environmental Protection Agency, 1998, Innovative technology verification report soil gas sampling technology: EPA/600/R-98/095.

U.S. Geological Survey, variously dated, National field manual for the collection of water-quality data: U.S. Geological Survey Techniques of Water-Resources Investigations, book 9, chaps. A1-A9, available online at http://pubs.water.usgs. gov/twri9A. Accessed March 26, 2012.

Williams, L.J., 2007, Hydrogeology and potentiometric surface of the Dublin and Midville aquifer systems in Richmond County, Georgia, January 2007: U.S. Geological Survey Scientific Investigations Map 2982, 1 sheet.

W.L. Gore and Associates, Inc., 2004, Surveys for environmental site assessment: Accessed March 19, 2010, at http://www.gore.com/MungoBlobs/239/659/surveys_ environmental_brochure.pdf. 
Table 1. Mass of organic compounds detected in soil-gas samplers, 310 underground storage tank, Fort Gordon, Georgia, 2010-2011.

[TPH, total petroleum hydrocarbons; $\mu \mathrm{g}$, micrograms; BTEX, summation of benzene, toluene, ethylbenzene, and total xylene; m, meta; p, para; o, ortho; MDL,method detection level; nd, not detected; bdl, below detection level; 662358,662359, 662360, 662361, and 662362 are trip blanks; MTBE, methyl tert-butyl ether; $\mathrm{C}_{11}, \mathrm{C}_{13}, \mathrm{C}_{15}$, combined masses of undecane, tridecane, and pentadecane; DCA dichloroethane; TCA, trchloroethane; TCE, trichloroethylene; PCE, perchloroethylene; $c$, cis; $t$, trans; DCE, dichloroethylene; $\mathrm{CCL}_{4}$, carbon tetrachloride; $\mathrm{DCB}$, dichlorobenzene. All units in micrograms per liter]

\begin{tabular}{|c|c|c|c|c|c|c|c|}
\hline $\begin{array}{l}\text { Sampler } \\
\text { number }\end{array}$ & TPH & BTEX & Benzene & Toluene & Ethlybenzene & m-,p-xylene & o-xylene \\
\hline MDL= & 0.02 & & 0.01 & 0.01 & 0.02 & 0.02 & 0.01 \\
\hline \multicolumn{8}{|c|}{ Environmental Samples } \\
\hline 662363 & 0.23 & 0.02 & nd & nd & nd & 0.02 & nd \\
\hline 662364 & 0.03 & nd & nd & nd & nd & nd & nd \\
\hline 662365 & bdl & nd & nd & nd & nd & nd & nd \\
\hline 662366 & 3.11 & nd & nd & nd & nd & nd & nd \\
\hline 662367 & 0.22 & 0.03 & 0.03 & nd & nd & nd & nd \\
\hline 662368 & 0.03 & nd & nd & nd & nd & nd & nd \\
\hline 662369 & 0.02 & nd & nd & nd & nd & nd & nd \\
\hline 662370 & bdl & nd & nd & nd & nd & nd & nd \\
\hline 662371 & 0.02 & nd & nd & nd & nd & nd & nd \\
\hline 662372 & 2.01 & nd & nd & nd & nd & nd & nd \\
\hline 662373 & 34.89 & 0.05 & nd & 0.05 & nd & nd & nd \\
\hline 662374 & 6.47 & nd & nd & nd & nd & nd & nd \\
\hline 662375 & 0.11 & nd & nd & nd & nd & nd & nd \\
\hline 662376 & 0.61 & nd & nd & nd & nd & nd & nd \\
\hline 662377 & 27.26 & 0.41 & nd & 0.41 & nd & nd & nd \\
\hline 662378 & 0.03 & nd & nd & nd & nd & nd & nd \\
\hline 662379 & 3.04 & nd & nd & nd & nd & nd & nd \\
\hline 662380 & 0.09 & nd & nd & nd & nd & nd & nd \\
\hline 662381 & 30.55 & 0.04 & nd & 0.04 & nd & nd & nd \\
\hline 662382 & 0.20 & nd & nd & nd & nd & nd & nd \\
\hline 662383 & 1.35 & nd & nd & nd & nd & nd & nd \\
\hline 662384 & 0.69 & 0.02 & 0.02 & nd & nd & nd & nd \\
\hline 662385 & 10.78 & 0.03 & nd & 0.03 & nd & nd & nd \\
\hline 662386 & 0.07 & nd & nd & nd & nd & nd & nd \\
\hline 662387 & 0.26 & nd & nd & nd & nd & nd & nd \\
\hline 662388 & 0.43 & nd & nd & nd & nd & nd & nd \\
\hline 662389 & 0.20 & nd & nd & nd & nd & nd & nd \\
\hline 662390 & 0.16 & nd & nd & nd & nd & nd & nd \\
\hline 662391 & 0.40 & nd & nd & nd & nd & nd & nd \\
\hline 662392 & 0.09 & nd & nd & nd & nd & nd & nd \\
\hline 662393 & 3.70 & nd & nd & nd & nd & nd & nd \\
\hline 662394 & 0.38 & nd & nd & nd & nd & nd & nd \\
\hline 662395 & 2.95 & 0.07 & 0.07 & nd & nd & nd & nd \\
\hline
\end{tabular}


Table 1. Mass of organic compounds detected in soil-gas samplers, 310 underground storage tank, Fort Gordon, Georgia, 2010-2011.-Continued

[TPH, total petroleum hydrocarbons; $\mu \mathrm{g}$, micrograms; BTEX, summation of benzene, toluene, ethylbenzene, and total xylene; m, meta; p, para; o, ortho; MDL, method detection level; nd, not detected; bdl, below detection level; 662358,662359, 662360, 662361, and 662362 are trip blanks; MTBE, methyl tert-butyl ether; $\mathrm{C}_{11}, \mathrm{C}_{13}, \mathrm{C}_{15}$, combined masses of undecane, tridecane, and pentadecane; DCA dichloroethane; TCA, trchloroethane; TCE, trichloroethylene; PCE, perchloroethylene; $c$, cis; $t$, trans; DCE, dichloroethylene; $\mathrm{CCL}_{4}$, carbon tetrachloride; $\mathrm{DCB}$, dichlorobenzene. All units in micrograms per liter]

\begin{tabular}{|c|c|c|c|c|c|c|c|}
\hline $\begin{array}{l}\text { Sampler } \\
\text { number }\end{array}$ & TPH & BTEX & Benzene & Toluene & Ethlybenzene & m-,p-xylene & 0-xylene \\
\hline MDL= & 0.02 & & 0.01 & 0.01 & 0.02 & 0.02 & 0.01 \\
\hline \multicolumn{8}{|c|}{ Environmental Samples-Continued } \\
\hline 662396 & 0.53 & nd & nd & nd & nd & nd & nd \\
\hline 662397 & 0.07 & nd & nd & nd & nd & nd & nd \\
\hline 662398 & 0.53 & nd & nd & nd & nd & nd & nd \\
\hline 662399 & 0.03 & nd & nd & nd & nd & nd & nd \\
\hline \multicolumn{8}{|c|}{ Trip Blanks } \\
\hline 662358 & bdl & nd & nd & nd & nd & nd & nd \\
\hline 662359 & 0.08 & nd & nd & nd & nd & nd & nd \\
\hline 662360 & bdl & nd & nd & nd & nd & nd & nd \\
\hline 662361 & nd & nd & nd & nd & nd & nd & nd \\
\hline 662362 & nd & nd & nd & nd & nd & nd & nd \\
\hline method blank & bdl & nd & nd & nd & nd & nd & nd \\
\hline method blank & nd & nd & nd & nd & nd & nd & nd \\
\hline Maximum & 34.89 & 0.41 & 0.07 & 0.41 & 0.00 & 0.02 & 0.00 \\
\hline $\begin{array}{l}\text { Standard } \\
\text { deviation }\end{array}$ & 8.55 & 0.07 & 0.01 & 0.07 & 0.00 & 0.00 & 0.00 \\
\hline Mean & 3.56 & 0.02 & 0.00 & 0.01 & 0.00 & 0.00 & 0.00 \\
\hline
\end{tabular}


Table 1. Mass of organic compounds detected in soil-gas samplers, 310 underground storage tank area, Fort Gordon, Georgia, 2010-2011.-Continued

[TPH, total petroleum hydrocarbons; $\mu \mathrm{g}$, micrograms; BTEX, summation of benzene, toluene, ethylbenzene, and total xylene; m, meta; p, para; o, ortho; MDL,method detection level; nd, not detected; bdl, below detection level; $662358,662359,662360,662361$, and 662362 are trip blanks; MTBE, methyl tert-butyl ether; $\mathrm{C}_{11}, \mathrm{C}_{13}, \mathrm{C}_{15}$, combined masses of undecane, tridecane, and pentadecane; DCA dichloroethane; TCA, trchloroethane; TCE, trichloroethylene; PCE, perchloroethylene; $c$, cis; t, trans; DCE, dichloroethylene; $\mathrm{CCL}_{4}$, carbon tetrachloride; DCB, dichlorobenzene. All units are in micrograms per liter]

\begin{tabular}{|c|c|c|c|c|}
\hline $\begin{array}{l}\text { Sampler } \\
\text { number }\end{array}$ & Naphthalene & $\begin{array}{l}\text { 2-Methyl- } \\
\text { Naphthalene }\end{array}$ & MTBE & Octane \\
\hline MDL= & 0.01 & 0.01 & 0.03 & 0.02 \\
\hline 662363 & nd & nd & nd & nd \\
\hline 662364 & nd & nd & nd & nd \\
\hline 662365 & nd & nd & nd & nd \\
\hline 662366 & bdl & nd & nd & nd \\
\hline 662367 & nd & nd & nd & nd \\
\hline 662368 & nd & nd & nd & nd \\
\hline 662369 & nd & nd & nd & nd \\
\hline 662370 & nd & nd & nd & nd \\
\hline 662371 & nd & nd & nd & nd \\
\hline 662372 & nd & nd & nd & nd \\
\hline 662373 & nd & bdl & nd & nd \\
\hline 662374 & nd & nd & nd & nd \\
\hline 662375 & nd & nd & nd & nd \\
\hline 662376 & nd & nd & nd & nd \\
\hline 662377 & nd & nd & nd & nd \\
\hline 662378 & nd & nd & nd & nd \\
\hline 662379 & nd & nd & nd & nd \\
\hline 662380 & nd & nd & nd & nd \\
\hline 662381 & nd & nd & nd & nd \\
\hline 662382 & nd & nd & nd & nd \\
\hline 662383 & nd & nd & nd & nd \\
\hline 662384 & nd & nd & nd & nd \\
\hline 662385 & nd & nd & nd & nd \\
\hline 662386 & nd & nd & nd & nd \\
\hline 662387 & nd & nd & nd & nd \\
\hline 662388 & nd & nd & nd & nd \\
\hline 662389 & nd & nd & nd & nd \\
\hline 662390 & nd & nd & nd & nd \\
\hline 662391 & nd & nd & nd & nd \\
\hline 662392 & nd & nd & nd & nd \\
\hline 662393 & nd & nd & nd & nd \\
\hline 662394 & nd & nd & nd & nd \\
\hline 662395 & nd & nd & nd & nd \\
\hline 662396 & nd & nd & nd & nd \\
\hline 662397 & nd & nd & nd & nd \\
\hline
\end{tabular}


Table 1. Mass of organic compounds detected in soil-gas samplers, 310 underground storage tank area, Fort Gordon, Georgia, 2010-2011.-Continued

$[\mathrm{TPH}$, total petroleum hydrocarbons; $\mu \mathrm{g}$, micrograms; BTEX, summation of benzene, toluene, ethylbenzene, and total xylene; m, meta; $p$, para; o, ortho; MDL,method detection level; nd, not detected; bdl, below detection level; 662358,662359, 662360, 662361, and 662362 are trip blanks; MTBE, methyl tert-butyl ether; $\mathrm{C}_{11}, \mathrm{C}_{13}, \mathrm{C}_{15}$, combined masses of undecane, tridecane, and pentadecane; DCA dichloroethane; TCA, trchloroethane; TCE, trichloroethylene; PCE, perchloroethylene; $c$, cis; t, trans; $\mathrm{DCE}$, dichloroethylene; $\mathrm{CCL}_{4}$, carbon tetrachloride; DCB, dichlorobenzene. All units are in micrograms per liter]

\begin{tabular}{ccccc}
\hline $\begin{array}{c}\text { Sampler } \\
\text { number }\end{array}$ & Naphthalene & $\begin{array}{c}\text { 2-Methyl-Naph- } \\
\text { thalene }\end{array}$ & MTBE & Octane \\
\hline MDL= & $\mathbf{0 . 0 1}$ & $\mathbf{0 . 0 1}$ & $\mathbf{0 . 0 3}$ & $\mathbf{0 . 0 2}$ \\
\hline 662398 & nd & nd & nd & nd \\
662399 & nd & nd & nd & nd \\
662358 & nd & nd & nd & nd \\
662359 & nd & nd & nd & nd \\
662360 & nd & nd & nd & nd \\
662361 & nd & nd & nd & nd \\
662362 & nd & nd & nd & nd \\
method blank & nd & nd & nd & nd \\
method blank & nd & nd & nd & nd \\
Maximum & 0.00 & 0.00 & 0.00 & 0.00 \\
Standard & 0.00 & 0.00 & 0.00 & 0.00 \\
deviation & & & & \\
Mean & 0.00 & 0.00 & 0.00 & 0.00 \\
\hline
\end{tabular}


Table 1. Mass of organic compounds detected in soil-gas samplers, 310 underground storage tank area, Fort Gordon, Georgia, 2010-2011.-Continued

[TPH, total petroleum hydrocarbons; $\mu \mathrm{g}$, micrograms; BTEX, summation of benzene, toluene, ethylbenzene, and total xylene; m, meta; p, para; o, ortho; MDL,method detection level; nd, not detected; bdl, below detection level; 662358,662359, 662360, 662361, and 662362 are trip blanks; MTBE, methyl tert-butyl ether; $\mathrm{C}_{11}, \mathrm{C}_{13}, \mathrm{C}_{15}$, combined masses of undecane, tridecane, and pentadecane; DCA dichloroethane; TCA, trchloroethane; TCE, trichloroethylene; PCE, perchloroethylene; $c$, cis; $t$, trans; DCE, dichloroethylene; $\mathrm{CCL}_{4}$, carbon tetrachloride; $\mathrm{DCB}$, dichlorobenzene. All units are in micrograms per liter]

\begin{tabular}{|c|c|c|c|c|}
\hline $\begin{array}{l}\text { Sampler } \\
\text { number }\end{array}$ & $C_{11}, C_{13^{\prime}} C_{15}$ & Undecane & Tridecane & Pentadecane \\
\hline MDL= & & 0.01 & 0.01 & 0.01 \\
\hline 662363 & nd & nd & nd & nd \\
\hline 662364 & nd & nd & nd & nd \\
\hline 662365 & nd & nd & nd & nd \\
\hline 662366 & 0.24 & 0.21 & 0.02 & nd \\
\hline 662367 & bdl & nd & nd & bdl \\
\hline 662368 & nd & nd & nd & nd \\
\hline 662369 & nd & nd & nd & nd \\
\hline 662370 & nd & nd & nd & nd \\
\hline 662371 & nd & nd & nd & nd \\
\hline 662372 & 0.67 & 0.64 & 0.03 & bdl \\
\hline 662373 & 0.02 & nd & 0.02 & nd \\
\hline 662374 & bdl & nd & nd & bdl \\
\hline 662375 & nd & nd & nd & nd \\
\hline 662376 & 0.02 & nd & nd & 0.02 \\
\hline 662377 & 0.04 & nd & nd & 0.04 \\
\hline 662378 & nd & nd & nd & nd \\
\hline 662379 & 0.12 & 0.12 & nd & nd \\
\hline 662380 & bdl & nd & nd & bdl \\
\hline 662381 & 19.03 & 16.63 & 1.45 & 0.95 \\
\hline 662382 & nd & nd & nd & nd \\
\hline 662383 & bdl & bdl & nd & nd \\
\hline 662384 & nd & nd & nd & nd \\
\hline 662385 & bdl & nd & nd & bdl \\
\hline 662386 & nd & nd & nd & nd \\
\hline 662387 & 0.01 & 0.01 & nd & nd \\
\hline 662388 & nd & nd & nd & nd \\
\hline 662389 & nd & nd & nd & nd \\
\hline 662390 & nd & nd & nd & nd \\
\hline 662391 & nd & nd & nd & nd \\
\hline 662392 & nd & nd & nd & nd \\
\hline 662393 & 0.01 & nd & nd & 0.01 \\
\hline 662394 & nd & nd & nd & nd \\
\hline 662395 & bdl & nd & nd & bdl \\
\hline 662396 & nd & nd & nd & nd \\
\hline 662397 & nd & nd & nd & nd \\
\hline 662398 & nd & nd & nd & nd \\
\hline
\end{tabular}


Table 1. Mass of organic compounds detected in soil-gas samplers, 310 underground storage tank area, Fort Gordon, Georgia, 2010-2011.-Continued

$[\mathrm{TPH}$, total petroleum hydrocarbons; $\mu \mathrm{g}$, micrograms; BTEX, summation of benzene, toluene, ethylbenzene, and total xylene; m, meta; , para; o, ortho; MDL, method detection level; nd, not detected; bdl, below detection level; 662358,662359, 662360, 662361, and 662362 are trip blanks; MTBE, methyl tert-butyl ether; $\mathrm{C}_{11}, \mathrm{C}_{13}, \mathrm{C}_{15}$, combined masses of undecane, tridecane, and pentadecane; DCA dichloroethane; TCA, trchloroethane; TCE, trichloroethylene; PCE, perchloroethylene; $c$, cis; $t$, trans; DCE, dichloroethylene; $\mathrm{CCL}_{4}$, carbon tetrachloride; $\mathrm{DCB}$, dichlorobenzene. All units are in micrograms per liter]

\begin{tabular}{ccccc}
\hline $\begin{array}{c}\text { Sampler } \\
\text { number }\end{array}$ & $\mathbf{C}_{11^{\prime}} \mathbf{C}_{\mathbf{1 3}^{\prime}} \mathbf{C}_{\mathbf{1 5}}$ & Undecane & Tridecane & Pentadecane \\
\hline MDL= & & $\mathbf{0 . 0 1}$ & $\mathbf{0 . 0 1}$ & $\mathbf{0 . 0 1}$ \\
\hline 662399 & bdl & nd & nd & bdl \\
662358 & nd & nd & nd & nd \\
662359 & bdl & bdl & bdl & bdl \\
662360 & nd & nd & nd & nd \\
662361 & nd & nd & nd & nd \\
662362 & nd & nd & nd & nd \\
method blank & nd & nd & nd & nd \\
method blank & nd & nd & nd & nd \\
Maximum & 19.03 & 16.63 & 1.45 & 0.95 \\
Standard & 3.13 & 2.73 & 0.24 & 0.16 \\
deviation & & & & \\
Mean & 0.54 & 0.48 & 0.04 & 0.03 \\
\hline
\end{tabular}


Table 1. Mass of organic compounds detected in soil-gas samplers, 310 underground storage tank area, Fort Gordon, Georgia, 2010-2011.-Continued

[TPH, total petroleum hydrocarbons; $\mu \mathrm{g}$, micrograms; BTEX, summation of benzene, toluene, ethylbenzene, and total xylene; m, meta; $\mathrm{p}$, para; o, ortho; MDL, method detection level; nd, not detected; bdl, below detection level; 662358,662359, 662360, 662361, and 662362 are trip blanks; MTBE, methyl tert-butyl ether; $\mathrm{C}_{11}, \mathrm{C}_{13}, \mathrm{C}_{15}$, combined masses of undecane, tridecane, and pentadecane; DCA dichloroethane; TCA, trchloroethane; TCE, trichloroethylene; PCE, perchloroethylene; c, cis; $t$, trans; DCE, dichloroethylene; $\mathrm{CCL}_{4}$, carbon tetrachloride; $\mathrm{DCB}$, dichlorobenzene All units are in micrograms per liter]

\begin{tabular}{|c|c|c|c|c|c|c|c|}
\hline $\begin{array}{l}\text { Sampler } \\
\text { number }\end{array}$ & $\begin{array}{l}\text { Trimethyl- } \\
\text { benzenes }\end{array}$ & $\begin{array}{c}\text { 1,2,4-Trimethyl- } \\
\text { benzene }\end{array}$ & $\begin{array}{c}\text { 1,3,5,-Trimethyl- } \\
\text { benzene }\end{array}$ & 1,1-DCA & Chloroform & 1,1,1-TCA & 1,2-DCA \\
\hline MDL= & & 0.01 & 0.02 & 0.02 & 0.01 & 0.01 & 0.01 \\
\hline 662363 & 0.02 & 0.02 & nd & nd & nd & nd & nd \\
\hline 662364 & nd & nd & nd & nd & nd & nd & nd \\
\hline 662365 & nd & nd & nd & nd & nd & nd & nd \\
\hline 662366 & nd & nd & nd & nd & nd & nd & nd \\
\hline 662367 & nd & nd & nd & nd & nd & nd & nd \\
\hline 662368 & nd & nd & nd & nd & nd & nd & nd \\
\hline 662369 & nd & nd & nd & nd & nd & nd & nd \\
\hline 662370 & nd & nd & nd & nd & nd & nd & nd \\
\hline 662371 & nd & nd & nd & nd & nd & nd & nd \\
\hline 662372 & nd & nd & nd & nd & nd & nd & nd \\
\hline 662373 & nd & nd & nd & nd & nd & nd & nd \\
\hline 662374 & nd & nd & nd & nd & nd & nd & nd \\
\hline 662375 & nd & nd & nd & nd & nd & nd & nd \\
\hline 662376 & nd & nd & nd & nd & nd & nd & nd \\
\hline 662377 & nd & nd & nd & nd & nd & nd & nd \\
\hline 662378 & nd & nd & nd & nd & nd & nd & nd \\
\hline 662379 & nd & nd & nd & nd & nd & nd & nd \\
\hline 662380 & nd & nd & nd & nd & nd & nd & nd \\
\hline 662381 & nd & nd & nd & nd & 0.05 & nd & nd \\
\hline 662382 & nd & nd & nd & nd & 0.06 & nd & nd \\
\hline 662383 & nd & nd & nd & nd & nd & nd & nd \\
\hline 662384 & nd & nd & nd & nd & nd & nd & nd \\
\hline 662385 & nd & nd & nd & nd & nd & nd & nd \\
\hline 662386 & nd & nd & nd & nd & 0.04 & nd & nd \\
\hline 662387 & nd & nd & nd & nd & 0.08 & nd & nd \\
\hline 662388 & nd & nd & nd & nd & nd & nd & nd \\
\hline 662389 & nd & nd & nd & nd & nd & nd & nd \\
\hline 662390 & nd & nd & nd & nd & 0.09 & nd & nd \\
\hline 662391 & nd & nd & nd & nd & 0.11 & nd & nd \\
\hline 662392 & nd & nd & nd & nd & nd & nd & nd \\
\hline 662393 & nd & nd & nd & nd & 0.10 & nd & nd \\
\hline 662394 & nd & nd & nd & nd & 0.04 & nd & nd \\
\hline 662395 & nd & nd & nd & nd & nd & nd & nd \\
\hline
\end{tabular}


Table 1. Mass of organic compounds detected in soil-gas samplers, 310 underground storage tank area, Fort Gordon, Georgia, 2010-2011.-Continued

[TPH, total petroleum hydrocarbons; $\mu \mathrm{g}$, micrograms; BTEX, summation of benzene, toluene, ethylbenzene, and total xylene; m, meta; p, para; o, ortho; MDL, method detection level; nd, not detected; bdl, below detection level; 662358,662359, 662360, 662361, and 662362 are trip blanks; MTBE, methyl tert-butyl ether; $\mathrm{C}_{11}, \mathrm{C}_{13}, \mathrm{C}_{15}$, combined masses of undecane, tridecane, and pentadecane; DCA dichloroethane; TCA, trchloroethane; TCE, trichloroethylene; PCE, perchloroethylene; c, cis; t, trans; DCE, dichloroethylene; $\mathrm{CCL}_{4}$, carbon tetrachloride; $\mathrm{DCB}$, dichlorobenzene. All units are in micrograms per liter]

\begin{tabular}{|c|c|c|c|c|c|c|c|}
\hline $\begin{array}{c}\text { Sampler } \\
\text { number }\end{array}$ & $\begin{array}{l}\text { Trimethyl- } \\
\text { benzenes }\end{array}$ & $\begin{array}{c}\text { 1,2,4-Trimethyl- } \\
\text { benzene }\end{array}$ & $\begin{array}{c}\text { 1,3,5,-Trimethyl- } \\
\text { benzene }\end{array}$ & 1,1-DCA & Chloroform & 1,1,1-TCA & 1,2-DCA \\
\hline MDL= & & 0.01 & 0.02 & 0.02 & 0.01 & 0.01 & 0.01 \\
\hline 662396 & nd & nd & nd & nd & nd & nd & nd \\
\hline 662397 & nd & nd & nd & nd & nd & nd & nd \\
\hline 662398 & nd & nd & nd & nd & nd & nd & nd \\
\hline 662399 & nd & nd & nd & nd & nd & nd & nd \\
\hline 662358 & nd & nd & nd & nd & nd & nd & nd \\
\hline 662359 & nd & nd & nd & nd & nd & nd & nd \\
\hline 662360 & nd & nd & nd & nd & nd & nd & nd \\
\hline 662361 & nd & nd & nd & nd & nd & nd & nd \\
\hline 662362 & nd & nd & nd & nd & nd & nd & nd \\
\hline method blank & nd & nd & nd & nd & nd & nd & nd \\
\hline method blank & nd & nd & nd & nd & nd & nd & nd \\
\hline Maximum & 0.02 & 0.02 & 0.00 & 0.00 & 0.11 & 0.00 & 0.00 \\
\hline $\begin{array}{l}\text { Standard } \\
\text { deviation }\end{array}$ & 0.00 & 0.00 & 0.00 & 0.00 & 0.03 & 0.00 & 0.00 \\
\hline Mean & 0.00 & 0.00 & 0.00 & 0.00 & 0.02 & 0.00 & 0.00 \\
\hline
\end{tabular}


Table 1. Mass of organic compounds detected in soil-gas samplers, 310 underground storage tank area, Fort Gordon, Georgia, 2010-2011.-Continued

[TPH, total petroleum hydrocarbons; $\mu \mathrm{g}$, micrograms; BTEX, summation of benzene, toluene, ethylbenzene, and total xylene; m, meta; p, para; o, ortho; MDL,method detection level; nd, not detected; bdl, below detection level; 662358,662359, 662360, 662361, and 662362 are trip blanks; MTBE, methyl tert-butyl ether; $\mathrm{C}_{11}, \mathrm{C}_{13}, \mathrm{C}_{15}$, combined masses of undecane, tridecane, and pentadecane; DCA dichloroethane; TCA, trchloroethane; TCE, trichloroethylene; PCE, perchloroethylene; $c$, cis; $t$, trans; DCE, dichloroethylene; $\mathrm{CCL}_{4}$, carbon tetrachloride; DCB, dichlorobenzene. All units are in micrograms per liter]

\begin{tabular}{|c|c|c|c|c|c|}
\hline $\begin{array}{l}\text { Sampler } \\
\text { number }\end{array}$ & TCE & PCE & $c, t-1,2-\mathrm{DCE}$ & $t-1,2-D C E$ & $c-1,2-\mathrm{DCE}$ \\
\hline MDL= & 0.02 & 0.02 & & 0.05 & 0.02 \\
\hline 662363 & nd & nd & nd & nd & nd \\
\hline 662364 & nd & nd & nd & nd & nd \\
\hline 662365 & nd & nd & nd & nd & nd \\
\hline 662366 & nd & nd & nd & nd & nd \\
\hline 662367 & nd & nd & nd & nd & nd \\
\hline 662368 & nd & nd & nd & nd & nd \\
\hline 662369 & nd & nd & nd & nd & nd \\
\hline 662370 & nd & nd & nd & nd & nd \\
\hline 662371 & nd & nd & nd & nd & nd \\
\hline 662372 & nd & nd & nd & nd & nd \\
\hline 662373 & nd & nd & nd & nd & nd \\
\hline 662374 & nd & nd & nd & nd & nd \\
\hline 662375 & nd & nd & nd & nd & nd \\
\hline 662376 & nd & nd & nd & nd & nd \\
\hline 662377 & nd & nd & nd & nd & nd \\
\hline 662378 & nd & nd & nd & nd & nd \\
\hline 662379 & nd & nd & nd & nd & nd \\
\hline 662380 & nd & nd & nd & nd & nd \\
\hline 662381 & nd & nd & nd & nd & nd \\
\hline 662382 & nd & 0.03 & nd & nd & nd \\
\hline 662383 & nd & nd & nd & nd & nd \\
\hline 662384 & nd & nd & nd & nd & nd \\
\hline 662385 & nd & nd & nd & nd & nd \\
\hline 662386 & nd & nd & nd & nd & nd \\
\hline 662387 & nd & nd & nd & nd & nd \\
\hline 662388 & nd & nd & nd & nd & nd \\
\hline 662389 & nd & nd & nd & nd & nd \\
\hline 662390 & nd & nd & nd & nd & nd \\
\hline 662391 & nd & nd & nd & nd & nd \\
\hline 662392 & nd & nd & nd & nd & nd \\
\hline 662393 & nd & nd & nd & nd & nd \\
\hline 662394 & nd & nd & nd & nd & nd \\
\hline 662395 & nd & nd & nd & nd & nd \\
\hline
\end{tabular}


Table 1. Mass of organic compounds detected in soil-gas samplers, 310 underground storage tank area, Fort Gordon, Georgia, 2010- 2011.-Continued

$[\mathrm{TPH}$, total petroleum hydrocarbons; $\mu \mathrm{g}$, micrograms; BTEX, summation of benzene, toluene, ethylbenzene, and total xylene; m, meta; , para; o, ortho; MDL, method detection level; nd, not detected; bdl, below detection level; 662358,662359, 662360, 662361, and 662362 are trip blanks; MTBE, methyl tert-butyl ether; $\mathrm{C}_{11}, \mathrm{C}_{13}, \mathrm{C}_{15}$, combined masses of undecane, tridecane, and pentadecane; DCA dichloroethane; TCA, trchloroethane; TCE, trichloroethylene; PCE, perchloroethylene; $c$, cis; $t$, trans; DCE, dichloroethylene; $\mathrm{CCL}_{4}$, carbon tetrachloride; $\mathrm{DCB}$, dichlorobenzene. All units are in micrograms per liter]

\begin{tabular}{cccccc}
\hline $\begin{array}{c}\text { Sampler } \\
\text { number }\end{array}$ & TCE & PCE & $\boldsymbol{c , t - 1 , 2 - D C E}$ & $\boldsymbol{t}$-1,2-DCE & $\boldsymbol{c}$-1,2-DCE \\
\hline MDL= & $\mathbf{0 . 0 2}$ & $\mathbf{0 . 0 2}$ & & $\mathbf{0 . 0 5}$ & $\mathbf{0 . 0 2}$ \\
\hline 662396 & nd & nd & nd & nd & nd \\
662397 & nd & nd & nd & nd & nd \\
662398 & nd & nd & nd & nd & nd \\
662399 & nd & nd & nd & nd & nd \\
662358 & nd & nd & nd & nd & nd \\
662359 & nd & nd & nd & nd & nd \\
662360 & nd & nd & nd & nd & nd \\
662361 & nd & nd & nd & nd & nd \\
662362 & nd & nd & nd & nd & nd \\
method blank & nd & nd & nd & nd & nd \\
method blank & nd & nd & nd & nd & nd \\
Maximum & 0.00 & 0.03 & 0.00 & 0.00 & 0.00 \\
Standard & & & & & \\
deviation & 0.00 & 0.00 & 0.00 & 0.00 & 0.00 \\
Mean & 0.00 & 0.00 & 0.00 & 0.00 & 0.00 \\
\hline
\end{tabular}


Table 1. Mass of organic compounds detected in soil-gas samplers, 310 underground storage tank area, Fort Gordon, Georgia, 2010-2011.-Continued

[TPH, total petroleum hydrocarbons; $\mu \mathrm{g}$, micrograms; BTEX, summation of benzene, toluene, ethylbenzene, and total xylene; m, meta; p, para; o, ortho; MDL, method detection level; nd, not detected; bdl, below detection level; 662358,662359, 662360, 662361, and 662362 are trip blanks; MTBE, methyl tert-butyl ether; $\mathrm{C}_{11}, \mathrm{C}_{13}, \mathrm{C}_{15}$, combined masses of undecane, tridecane, and pentadecane; DCA dichloroethane; TCA, trchloroethane; TCE, trichloroethylene; PCE, perchloroethylene; $c$, cis; $t$, trans; DCE, dichloroethylene; $\mathrm{CCL}_{4}$, carbon tetrachloride; DCB, dichlorobenzene. All units are in micrograms per liter]

\begin{tabular}{|c|c|c|c|c|c|c|}
\hline $\begin{array}{l}\text { Sampler } \\
\text { number }\end{array}$ & $\mathrm{CCl}_{4}$ & 1,4-DCB $(\mu \mathrm{g})$ & 1,1,2-TCA & Chlorobenzene & $\begin{array}{l}\text { 1,1,1,2-Tetra- } \\
\text { chloroethane }\end{array}$ & $\begin{array}{l}\text { 1,1,2,2-Tetra- } \\
\text { chlorethane }\end{array}$ \\
\hline MDL= & 0.03 & 0.01 & 0.02 & 0.03 & 0.02 & 0.01 \\
\hline 662363 & nd & nd & nd & nd & nd & nd \\
\hline 662364 & nd & nd & nd & nd & nd & nd \\
\hline 662365 & nd & nd & nd & nd & nd & nd \\
\hline 662366 & nd & nd & nd & nd & nd & nd \\
\hline 662367 & nd & nd & nd & nd & nd & nd \\
\hline 662368 & nd & nd & nd & nd & nd & nd \\
\hline 662369 & nd & nd & nd & nd & nd & nd \\
\hline 662370 & nd & nd & nd & nd & nd & nd \\
\hline 662371 & nd & nd & nd & nd & nd & nd \\
\hline 662372 & nd & nd & nd & nd & nd & nd \\
\hline 662373 & nd & nd & nd & nd & nd & nd \\
\hline 662374 & nd & nd & nd & nd & nd & nd \\
\hline 662375 & nd & nd & nd & nd & nd & nd \\
\hline 662376 & nd & nd & nd & nd & nd & nd \\
\hline 662377 & nd & nd & nd & nd & nd & nd \\
\hline 662378 & nd & nd & nd & nd & nd & nd \\
\hline 662379 & nd & nd & nd & nd & nd & nd \\
\hline 662380 & nd & nd & nd & nd & nd & nd \\
\hline 662381 & nd & nd & nd & nd & nd & nd \\
\hline 662382 & nd & nd & nd & nd & nd & nd \\
\hline 662383 & nd & nd & nd & nd & nd & nd \\
\hline 662384 & nd & nd & nd & nd & nd & nd \\
\hline 662385 & nd & nd & nd & nd & nd & nd \\
\hline 662386 & nd & nd & nd & nd & nd & nd \\
\hline 662387 & nd & nd & nd & nd & nd & nd \\
\hline 662388 & nd & nd & nd & nd & nd & nd \\
\hline 662389 & nd & nd & nd & nd & nd & nd \\
\hline 662390 & nd & nd & nd & nd & nd & nd \\
\hline 662391 & nd & nd & nd & nd & nd & nd \\
\hline 662392 & nd & nd & nd & nd & nd & nd \\
\hline 662393 & nd & nd & nd & nd & nd & nd \\
\hline
\end{tabular}


Table 1. Mass of organic compounds detected in soil-gas samplers, 310 underground storage tank area, Fort Gordon, Georgia, 2010-2011.-Continued

[TPH, total petroleum hydrocarbons; $\mu \mathrm{g}$, micrograms; BTEX, summation of benzene, toluene, ethylbenzene, and total xylene; m, meta; p, para; o, ortho; MDL,method detection level; nd, not detected; bdl, below detection level; 662358,662359, 662360, 662361, and 662362 are trip blanks; MTBE, methyl tert-butyl ether; $\mathrm{C}_{11}, \mathrm{C}_{13}, \mathrm{C}_{15}$, combined masses of undecane, tridecane, and pentadecane; DCA dichloroethane; TCA, trchloroethane; TCE, trichloroethylene; PCE, perchloroethylene; $c$, cis; $t$, trans; DCE, dichloroethylene; $\mathrm{CCL}_{4}$, carbon tetrachloride; DCB, dichlorobenzene. All units are in micrograms per liter]

\begin{tabular}{|c|c|c|c|c|c|c|}
\hline $\begin{array}{c}\text { Sampler } \\
\text { number }\end{array}$ & $\mathrm{CCl}_{4}$ & 1,4-DCB ( $\mu \mathrm{g})$ & 1,1,2-TCA & Chlorobenzene & $\begin{array}{l}\text { 1,1,1,2-Tetra- } \\
\text { chloroethane }\end{array}$ & $\begin{array}{l}\text { 1,1,2,2-Tetra- } \\
\text { chlorethane }\end{array}$ \\
\hline MDL= & 0.03 & 0.01 & 0.02 & 0.03 & 0.02 & 0.01 \\
\hline 662394 & nd & nd & nd & nd & nd & nd \\
\hline 662395 & nd & nd & nd & nd & nd & nd \\
\hline 662396 & nd & nd & nd & nd & nd & nd \\
\hline 662397 & nd & nd & nd & nd & nd & nd \\
\hline 662398 & nd & nd & nd & nd & nd & nd \\
\hline 662399 & nd & nd & nd & nd & nd & nd \\
\hline 662358 & nd & nd & nd & nd & nd & nd \\
\hline 662359 & nd & nd & nd & nd & nd & nd \\
\hline 662360 & nd & nd & nd & nd & nd & nd \\
\hline 662361 & nd & nd & nd & nd & nd & nd \\
\hline 662362 & nd & nd & nd & nd & nd & nd \\
\hline $\begin{array}{l}\text { method } \\
\text { blank }\end{array}$ & nd & nd & nd & nd & nd & nd \\
\hline $\begin{array}{l}\text { method } \\
\text { blank }\end{array}$ & nd & nd & nd & nd & nd & nd \\
\hline Maximum & 0.00 & 0.00 & 0.00 & 0.00 & 0.00 & 0.00 \\
\hline $\begin{array}{l}\text { Standard } \\
\text { Dev. }\end{array}$ & 0.00 & 0.00 & 0.00 & 0.00 & 0.00 & 0.00 \\
\hline Mean & 0.00 & 0.00 & 0.00 & 0.00 & 0.00 & 0.00 \\
\hline
\end{tabular}


Table 1. Mass of organic compounds detected in soil-gas samplers, 310 underground storage tank area, Fort Gordon, Georgia, 2010-2011.-Continued

[TPH, total petroleum hydrocarbons; $\mu \mathrm{g}$, micrograms; BTEX, summation of benzene, toluene, ethylbenzene, and total xylene; m, meta; $p$, para; o, ortho; MDL,method detection level; nd, not detected; bdl, below detection level; 662358,662359, 662360, 662361, and 662362 are trip blanks; MTBE, methyl tert-butyl ether; $\mathrm{C}_{11}, \mathrm{C}_{13}, \mathrm{C}_{15}$, combined masses of undecane, tridecane, and pentadecane; DCA dichloroethane; TCA, trchloroethane; TCE, trichloroethylene; PCE, perchloroethylene; $c$, cis; t, trans; DCE, dichloroethylene; $\mathrm{CCL}_{4}$, carbon tetrachloride; DCB, dichlorobenzene. All units are in micrograms per liter]

\begin{tabular}{|c|c|c|}
\hline $\begin{array}{l}\text { Sampler } \\
\text { number }\end{array}$ & 1,3-Dichlorobenzene & 1,2-Dichlorobenzene \\
\hline MDL= & 0.01 & 0.01 \\
\hline 662363 & nd & nd \\
\hline 662364 & nd & nd \\
\hline 662365 & nd & nd \\
\hline 662366 & nd & nd \\
\hline 662367 & nd & nd \\
\hline 662368 & nd & nd \\
\hline 662369 & nd & nd \\
\hline 662370 & nd & nd \\
\hline 662371 & nd & nd \\
\hline 662372 & nd & nd \\
\hline 662373 & nd & nd \\
\hline 662374 & nd & nd \\
\hline 662375 & nd & nd \\
\hline 662376 & nd & nd \\
\hline 662377 & nd & nd \\
\hline 662378 & nd & nd \\
\hline 662379 & nd & nd \\
\hline 662380 & nd & nd \\
\hline 662381 & nd & nd \\
\hline 662382 & nd & nd \\
\hline 662383 & nd & nd \\
\hline 662384 & nd & nd \\
\hline 662385 & nd & nd \\
\hline 662386 & nd & nd \\
\hline 662387 & nd & nd \\
\hline 662388 & nd & nd \\
\hline 662389 & nd & nd \\
\hline 662390 & nd & nd \\
\hline 662391 & nd & nd \\
\hline 662392 & nd & nd \\
\hline 662393 & nd & nd \\
\hline 662394 & nd & nd \\
\hline 662395 & nd & nd \\
\hline 662396 & nd & nd \\
\hline 662397 & nd & nd \\
\hline
\end{tabular}


Table 1. Mass of organic compounds detected in soil-gas samplers, 310 underground storage tank area, Fort Gordon, Georgia, 2010-2011.-Continued

$[\mathrm{TPH}$, total petroleum hydrocarbons; $\mu \mathrm{g}$, micrograms; BTEX, summation of benzene, toluene, ethylbenzene, and total xylene; m, meta; $p$, para; o, ortho; MDL,method detection level; nd, not detected; bdl, below detection level; 662358,662359, 662360, 662361, and 662362 are trip blanks; MTBE, methyl tert-butyl ether; $\mathrm{C}_{11}, \mathrm{C}_{13}, \mathrm{C}_{15}$, combined masses of undecane, tridecane, and pentadecane; DCA dichloroethane; TCA, trchloroethane; TCE, trichloroethylene; PCE, perchloroethylene; $c$, cis; t, trans; $\mathrm{DCE}$, dichloroethylene; $\mathrm{CCL}_{4}$, carbon tetrachloride; DCB, dichlorobenzene. All units are in micrograms per liter]

\begin{tabular}{ccc}
\hline $\begin{array}{c}\text { Sampler } \\
\text { number }\end{array}$ & 1,3-Dichlorobenzene & 1,2-Dichlorobenzene \\
\hline MDL= & $\mathbf{0 . 0 1}$ & $\mathbf{0 . 0 1}$ \\
\hline 662398 & nd & nd \\
662399 & nd & nd \\
662358 & nd & nd \\
662359 & nd & nd \\
662360 & nd & nd \\
662361 & nd & nd \\
662362 & nd & nd \\
method blank & nd & nd \\
method blank & nd & nd \\
Maximum & 0.00 & 0.00 \\
Standard Dev. & 0.00 & 0.00 \\
Mean & 0.00 & 0.00 \\
\hline
\end{tabular}




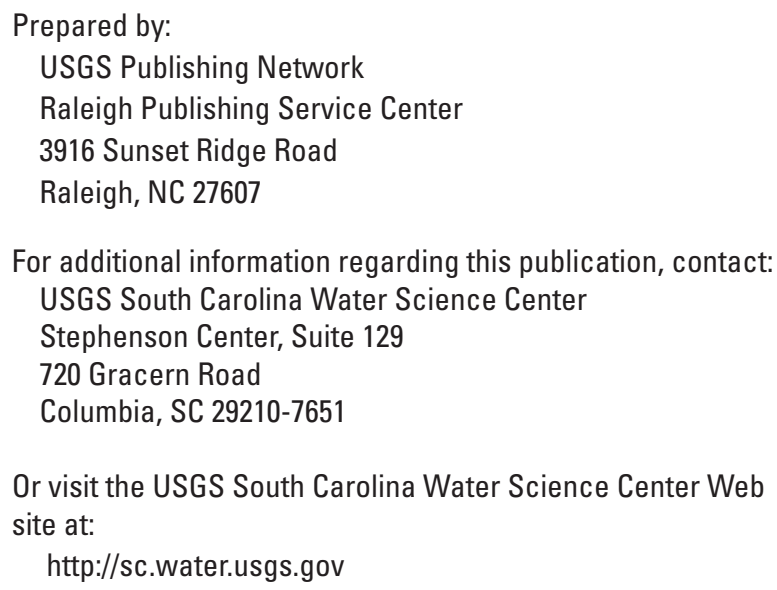

For additional information regarding this publication, contact: USGS South Carolina Water Science Center 



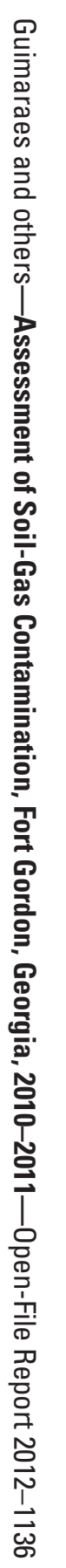

